\title{
Social participation in working-age adults with aphasia: An updated systematic review
}

$$
\text { by }
$$

\section{Caitlin Pike}

A dissertation submitted in fulfilment of the requirements for the degree

$$
\text { MA (Speech-Language Pathology) }
$$

in the Department of Speech-Language Pathology and Audiology at the

UNIVERSITY OF PRETORIA

FACULTY OF HUMANITIES

Supervisor: Prof. Alta Kritzinger

Co-supervisor: Mrs Bhavani Pillay

May 2017 


\section{UNIVERSITY OF PRETORIA}

\section{DEPARTMENT OF SPEECH-LANGUAGE PATHOLOGY AND AUDIOLOGY}

\begin{tabular}{|l|l|}
\hline Surname & Pike \\
\hline Initials & C \\
\hline Research supervisors & $\begin{array}{l}\text { Prof. Alta Kritzinger } \\
\text { Mrs Bhavani Pillay }\end{array}$ \\
\hline Date & $15 / 05 / 2017$ \\
\hline Title & $\begin{array}{l}\text { Social participation in working-age adults with aphasia: An updated } \\
\text { systematic review }\end{array}$ \\
\hline
\end{tabular}

Abstract

Background: A previous systematic review found limited data regarding social participation in working-age people with aphasia (PWA). This population has many roles to fulfill, that are negatively affected by aphasia. A review of recent studies may reveal more information on the challenges in re-establishing social roles and thus may inform treatment thereof.

Method: The aim was to provide an updated systematic review on social participation in PWA under 65 years of age. Studies from 2005-2017 were searched from Scopus, Pubmed and Psychinfo. Search terms were derived from the International Classification of Functioning, Disability and Health (ICF) and the AphasiaFramework for Outcomes Measures (A-FROM). Aspects of domestic life, interpersonal relations and interactions, education and employment and community, civic and social life were investigated.

Results: From 2,864 initial hits, 11 studies were identified, all of which were on the American SpeechLanguage-Hearing Association (ASHA) Level III of evidence. The studies indicated that participation in domestic life is reduced and PWA showed reduced social networks, loss of friendships and changes in the quality of marital relations. Few PWA returned to work or spent time on education. Limitations in community, civic and social life were noted and there were contradictory findings on the impact of contextual factors on social participation. There was an increase in research into contextual factors impacting on social participation in PWA and in the use of conceptual frameworks in the last decade.

Conclusions: Social participation in working-age adults is limited across the social domains. While the ICF conceptual framework is increasingly used, no studies used the A-FROM. There is greater use of standardised assessments and larger sample sizes.

Keywords: stroke, aphasia; social participation, working-age, young, middle-age, International Classification of Functioning, Disability and Health (ICF), Aphasia- Framework for Outcomes Measures (A-FROM) 


\section{UNIVERSITY OF PRETORIA}

FACULTY OF HUMANITIES

DEPARTMENT SPEECH-LANGUAGE PATHOLOGY AND AUDIOLOGY

\section{DECLARATION}

Full Name:

Student Number:

Degree:

I declare that this research report is my own original work. Where secondary material is used, this has been carefully acknowledged and referenced in accordance with university requirements.

I understand what plagiarism is and am aware of the University of Pretoria's policy in this regard.

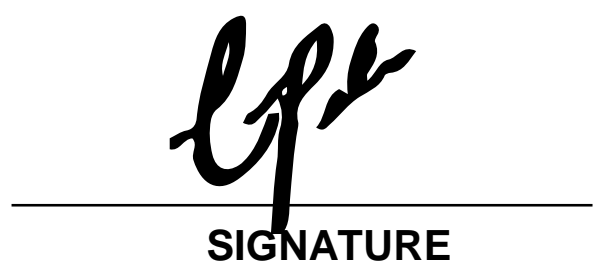

$15 / 05 / 2017$

\section{DATE}




\section{Acknowledgements}

Special thanks go to Professor Alta Kritzinger and Bhavani Pillay, the research supervisors, for their patience, guidance and assistance. This study would not have been possible without them.

I would like to thank my family and friends for their encouragement and support during this entire process. Lastly, unending thanks goes to my Heavenly Father. 


\section{TABLE OF CONTENTS}

LIST OF ABBREVIATIONS

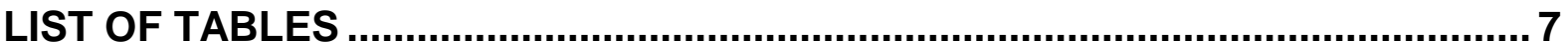

Table 1. Characteristics of included studies ................................................ 7

Table 2. Quality assessment and level of evidence of selected studies ....... 7

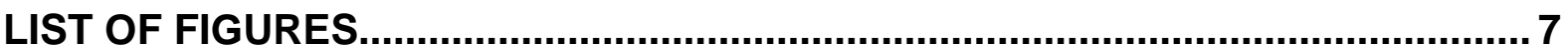

Figure 1. World Health Organisation International Classification of

Functioning, Disability and Health framework .............................. 7

Figure 2. PRISMA flow-chart of selection process ...................................... 7

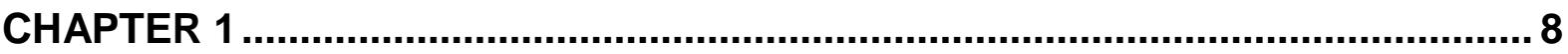

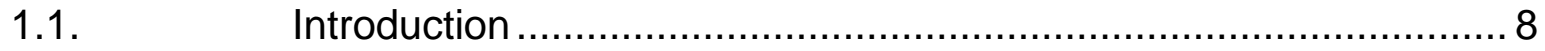

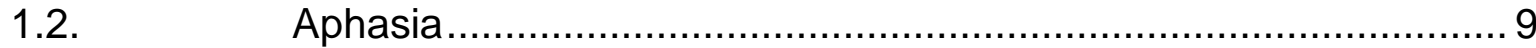

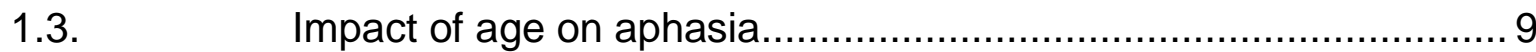

1.4. Impact of aphasia on short and long-term functional outcomes.... 11

1.5. The shift towards participation .............................................. 12

1.6. Social participation in working-age adults ................................. 14

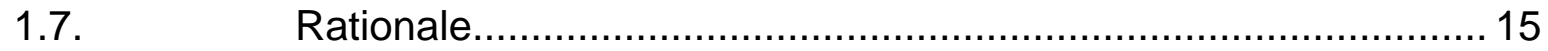

1.8. Terminology as used in the dissertation.................................... 15

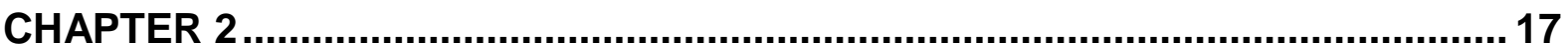

2.1. Aim

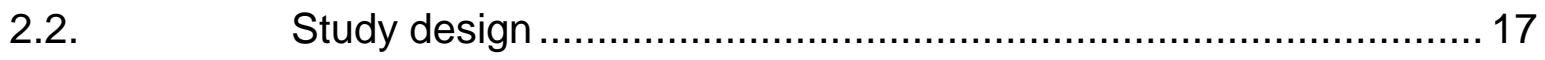

2.3. Study inclusion criteria ....................................................... 18

2.4. Study selection .............................................................. 18

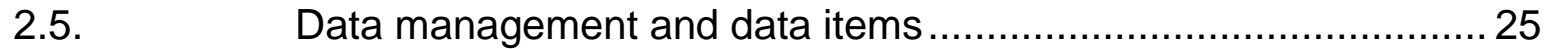

2.6. Risk of bias in selected studies .................................................... 25

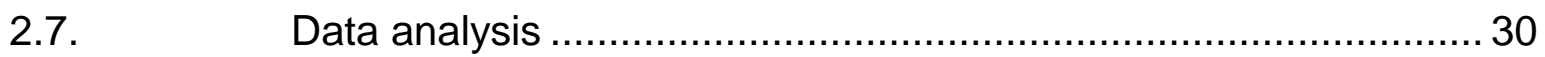

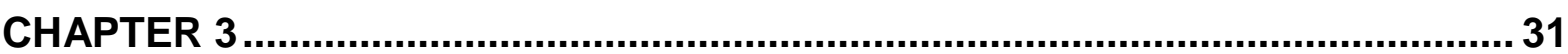

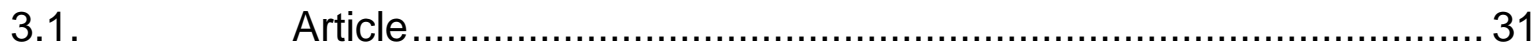

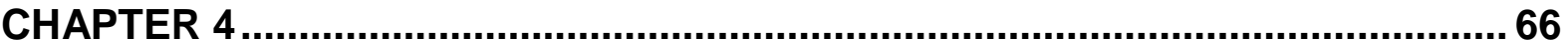

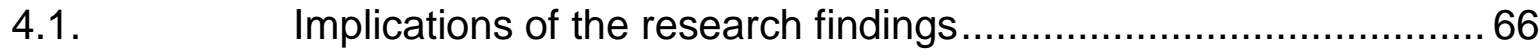

4.2. Limitations in the study ........................................................... 70

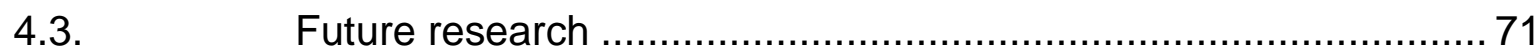

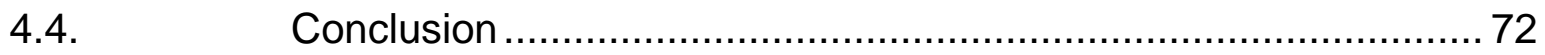




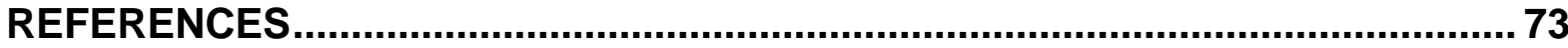

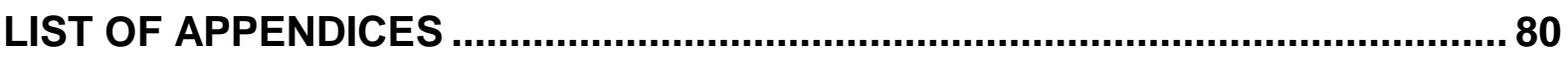

APPENDIX A: PRISMA-P checklist ..................................................... 81

APPENDIX B: Newcastle-Ottawa Quality Assessment Scale adapted for crosssectional studies ............................................................... 82

APPENDIX C: Proof of submission to Topics in Stroke Rehabilitation.................. 83 


\section{LIST OF ABBREVIATIONS}

A-FROM - $\quad$ Aphasia- Framework for Outcome Measurement

ASHA $\quad-\quad$ American Speech-Language-Hearing Association

BMI - Body Mass Index

CVA $\quad$ - $\quad$ Cerebral Vascular Accident

FIM - $\quad$ Functional Independence Measure

HRQL $\quad$ - $\quad$ Health Related Quality of Life

ICF $\quad$ - $\quad$ World Health Organisation International Classification of

Functioning, Disability and Health

LPAA $\quad$ - $\quad$ Life Participation Approach to Aphasia

MRI - $\quad$ - Magnetic Resonance Imaging

NOS - - Newcastle-Ottawa Quality Assessment Scale

NPO - Non-Profit Organisation

OT - Occupational Therapist

PRISMA-P - $\quad$ Preferred Reporting Items for Systematic Reviews and MetaAnalyses Protocols

PWA $\quad$ - $\quad$ Person with Aphasia

Q - $\quad$ Quantitative

QL $\quad$ - $\quad$ Qualitative

QOL $\quad$ - $\quad$ Quality of Life

R $\quad$ - Range

SD $\quad$ - $\quad$ Standard Deviation

SLT - $\quad$ Speech-Language Therapist 


\section{LIST OF TABLES}

Table 1. Characteristics of included studies

Table 2. Quality assessment and level of evidence of selected studies

\section{LIST OF FIGURES}

Figure 1. World Health Organisation International Classification of Functioning, Disability and Health framework

Figure 2. PRISMA flow-chart of selection process 


\section{CHAPTER 1}

\section{Aim of the chapter:}

The aim of this chapter is to orientate the reader to the topic of aphasia in working-age adults and resulting social participation difficulties, state the research problem, present a literature overview of related studies and to conclude with the rationale, research question of the study and the terminology as used in the dissertation.

\subsection{Introduction}

Worldwide, stroke is included among the foremost causes of long-term disability and often results in decreased quality of life (QOL) and work ability (Bohra et al., 2015; R. J. P. Dalemans, De Witte, Wade, \& Van den Heuvel, 2008). Global stroke incidence rates range from 41 to 316 per 100000 population, per year (Thrift et al., 2014). Within the upper margin of this range is the Agincourt rural sub-district of South Africa, with an estimated crude stroke incidence of 244 per 100000 person years ${ }^{1}$ (Maredza, Bertram \& Tollman, 2015). A study conducted in the Greater Cincinnati/Northern Kentucky region indicates that there is a significant increase in stroke incidence rates between the ages of 20 and 54 years (Kissela et al., 2012).

This concerning increase in strokes in the young and middle-age population may be related to a number of factors. The prevalence of the risk factors for stroke is changing in the working-age population, with a significant increase in diabetes, high cholesterol and obesity over time (Kissela et al., 2012). Kissela et al. (2012) found a marked increase in coronary heart disease and an increased rate of drug abuses was noted over time in young individuals with stroke. Maredza, Bertram, GómezOlivé, and Tollman (2016) found that high blood pressure and a high Body Mass

\footnotetext{
${ }^{1}$ Refers to the number of new cases within a population at risk, in a specified time period. The incidence proportion (number of new cases within a specified time period divided by the size of the population at risk) is divided by the number of years over which the population was studied.
} 
Index (BMI) were associated with a significant portion of the stroke burden in rural South Africa. In addition, it may be that with the advances in technology and the use of Magnetic Resonance Imaging (MRI), a greater number of strokes are being detected in the young, who have been shown to undergo more MRIs than older patients (Kissela et al., 2012). The increase in stroke in the working-age population is of particular concern to speech-language therapists due to the frequently presenting aphasia and its wide-spread consequences.

\subsection{Aphasia}

One of the main manifestations of stroke is aphasia, with a frequency ranging from 21 to $38 \%$ (Croquelois \& Bogousslavsky, 2011; Dickey et al., 2010; Hoffmann \& Chen, 2013; Pedersen, Vinter, \& Olsen, 2004). The frequency variation is due to differences in diagnostic criteria, post-stroke time period prior to evaluation as well as the selection criteria of the participants in studies (Kyrozis et al., 2009). Aphasia is an acquired neurogenic disorder that involves language difficulties that may affect reading, writing, comprehending and expressing language, not due to difficulties with sensation, motor functioning or intellect (Chapey, 2008). Aphasia is often classified into subtypes based on the presenting symptoms and the manner in which each modality is affected. These subtypes include fluent aphasias (Wernicke's aphasia, conduction aphasia and transcortical sensory aphasia), non-fluent aphasias (Broca's, transcortical motor and global aphasia) and anomic aphasia (Chapey, 2008). Researchers have found some discrepancy in the frequency of the presentation of the subtypes of aphasia. Global aphasia tends to be the most frequent type of aphasia identified (Kang et al., 2010; Pedersen et al., 2004). Kang et al. (2010) identify anomic aphasia as relatively on par with Broca's aphasia in frequency, followed by anomic aphasia, while Pedersen et al. (2004) identifies Wernicke's aphasia as occurring more frequently than Broca's aphasia in the acute stage. Aphasias have been found to be heterogeneous in both the aetiology and subtype of aphasia (Hoffmann \& Chen, 2013).

\subsection{Impact of age on aphasia}

It appears that age is another factor contributing to the heterogeneous nature of aphasia. Research indicates that young people with aphasia (PWA) are a unique 
population. Advancing age has been shown to be associated with an increased risk of aphasia (Dickey et al., 2010; Plowman, Hentz, \& Ellis, 2012). In first ischemic stroke individuals, age has been found to be a predictor for aphasia, with the risk increasing by 4\% with each year (Engelter et al., 2006; Kadojić et al., 2012). The type of stroke can be classified as ischemic (blocked blood vessel) or haemorrhagic (burst blood vessel) in origin (Andersen, Olsen, Dehlendorff, \& Kammersgaard, 2009). A haemorrhagic stroke occurs less frequently than an ischemic stroke (approximately ten times less frequently), but tends to be associated with a higher mortality risk or a stroke of a greater severity (Andersen et al., 2009).

Younger individuals more often present with non-fluent aphasia, while older individuals are more likely to present with fluent aphasia (Croquelois \& Bogousslavsky, 2011; Eslinger \& Damasio, 1981; Plowman et al., 2012). It appears that with age and possible neuropathological variation, a stroke located near the middle cerebral artery will either shift more posteriorly (leading to Wernicke's aphasia) or cover most of the middle cerebral artery region (leading to global aphasia) (Eslinger \& Damasio, 1981; Godefroy, Dubois, Debachy, Leclerc, \& Kreisler, 2002). While a difference in aphasia symptoms and types is evident across ages, Godefroy et al. (2002) found that this is true for ischemic strokes only, with adults with conduction aphasia being younger and those with subcortical aphasias being older. It appears that the age-aphasia association is related to the effects of ageing on vascular pathology and therefore the lesion location (Godefroy et al., 2002).

It appears that the age difference does not have a significant impact on the symptoms of aphasia in the acute stage but rather in the chronic stage (Godefroy et al., 2002; Pedersen et al., 2004). This may be due to a number of reasons, one of which is that the 'true' aphasia type may be masked by initial non-fluency in the acute stage, as most patients progress from non-fluent to fluent aphasia types. Pedersen et al. (2004) also suggest that the hypothesis of the lateralisation of comprehension in the brain with increasing age and possible reductions in brain plasticity at an older age, particularly for comprehension, may result in this finding. Furthermore, older patients may have early and undiagnosed Alzheimer's disease, 
which may contribute to the receptive difficulties evident at assessment (Pedersen et al., 2004).

There is considerable controversy in the literature regarding the impact of age on prognosis in recovery in aphasia. Some research supports the theory that prognosis deteriorates with an increase in age (Ali, Lyden, \& Brady, 2015; Laska, Hellblom, Murray, Kahan, \& Von Arbin, 2001; Tsouli, Kyritsis, Tsagalis, Virvidaki, \& Vemmos, 2009) and others do not (Liang et al., 2001; Pedersen et al., 2004). Plowman et al. (2012) conclude in their review that while age has been identified as a prognostic indicator for stroke recovery, this has not specifically been determined for aphasia or language recovery, likely due to the wide variety of factors that impact on language in an individual.

\subsection{Impact of aphasia on short and long-term functional outcomes}

While there are variations in the impact of age on aphasia and recovery, it is well known that aphasia, in general, is one of the strongest predictors of poor functional recovery and social outcome following a stroke (Fang et al., 2003). Aphasia may result in significant short and long-term challenges. Short-term, the presence of aphasia is associated with longer hospital stays and extended use of rehabilitation services (Dickey et al., 2010). PWA present with lower Functional Independence Measure (FIM) scores (both cognitive and motor) on admission to and discharge from hospitals or rehabilitation centres (Gialanella, Bertolinelli, Lissi, \& Prometti, 2011). PWA are less likely to return home as compared to individuals with stroke, but without aphasia (Gialanella et al., 2011).

Long-term, Dalemans et al. (2008) found that working-age PWA show decreased participation in numerous life areas due to the often significant communication difficulties. Dalemans et al. (2008) found a reduction in domestic life; alteration in interactions and relationships as well as changes in roles as partner, family member, parent, friend and citizen following the onset of aphasia. PWA show a reduction in the number of social contacts and a shift from relationships with friends and family to professionals (R. J. P. Dalemans et al., 2008). PWA between the ages of 15 and 49 show decreased employment rates as opposed to adults without aphasia, but in the same age group (Naess, Hammersvik, \& Skeie, 2009). Furthermore, it appears that 
should the PWA return to work, it is often at a less demanding level (R. J. P. Dalemans et al., 2008). These wide-spread restrictions are of concern as research shows that activity limitations negatively impact on health related quality of life (HRQL) in PWA (Hilari, Needle, \& Harrison, 2012).

\subsection{The shift towards participation}

In an attempt to facilitate functional outcomes in PWA, a number of social and life participation approaches have been developed. The goal for using these frameworks and approaches is to maximise re-engagement in life and to improved functional participation of PWA in the context of their individual lives and activities (Kagan \& Simmons-Mackie, 2007; Roth \& Worthington, 2005). One such approach is the Life Participation Approach to Aphasia (LPAA\}, which emphasises the concerns of the PWA within the treatment and decision-making process (Hallowell, 2017). Another framework, the World Health Organisation International Classification of Functioning, Disability and Health [ICF] (Hallowell, 2017; World Health Organisation [WHO], 2001), views health conditions according to two domains, namely 'Functioning and disability' and 'Contextual factors' (Figure 1).

\section{Health Condition}

(disorder or disease)

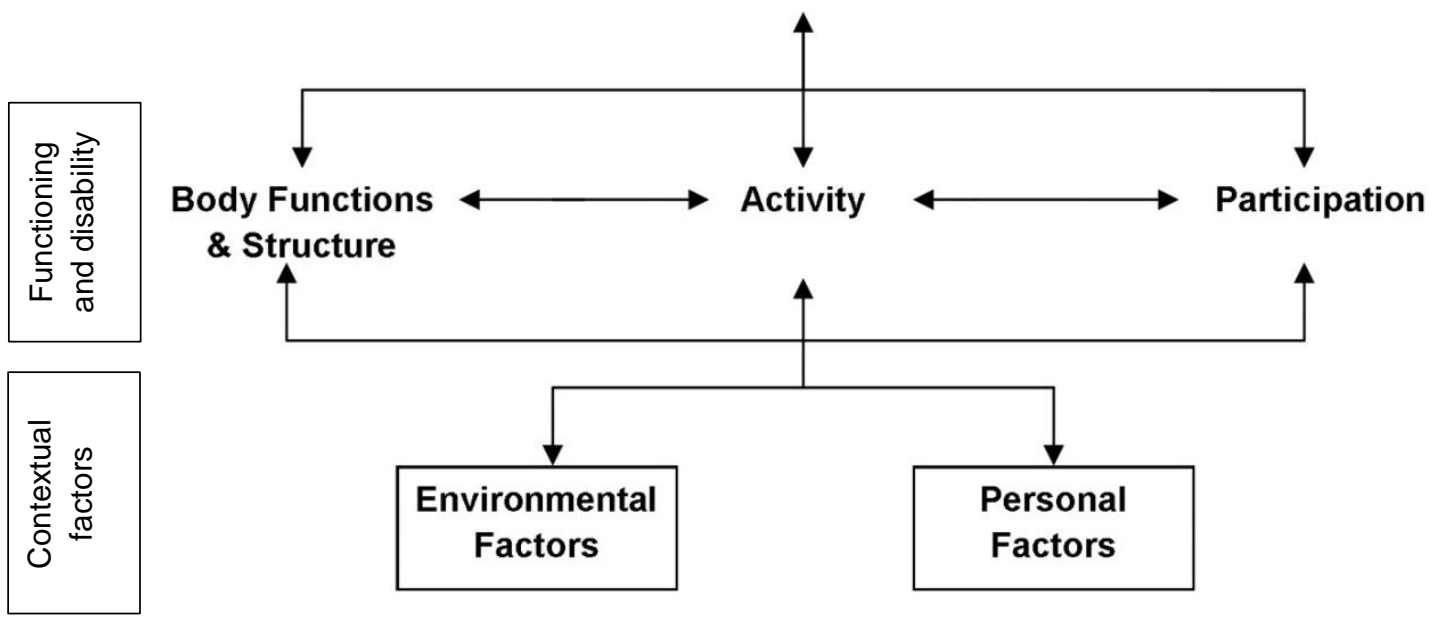

Figure 1. World Health Organisation International Classification of Functioning, Disability and Health framework

This approach helps to direct the focus to health, well-being and QOL, rather than to just the primary impairment (Hallowell, 2017). The multiple independent domains, 
including Body Function and Structure (one's physiological functioning and the anatomical parts of one's body), Activities and Participation (the execution of tasks and the involvement in a life situation) and Environment and Personal factors (personal, social and attitudinal environment), interrelate to create QOL of the individual (WHO, 2001). The condition alone does not impact the degree to which an individual participates in life; the three domains interact to facilitate or decrease participation and QOL. A conceptual guide has also been developed for aphasia that is compatible with the ICF, namely the Living with Aphasia-Framework for Outcome Measurements [A-FROM] (Kagan et al., 2008). This conceptual framework was developed to guide outcome measurement in aphasia, with emphasis on real-life outcomes. It integrates QOL and domains related to the environment, participation, and personal identity in the same framework as the impairment (Kagan et al., 2008). This conceptual guide was informed by the social model of disability, whose proponents see disability in the context of society. Poor participation is seen as a result of barriers in society and the view of both the individual and people around them that disability is a problem. The disability itself is seen as far less important than the impact of the condition on engagement in meaningful activity (Hallowell, 2017). Byng and Duchan (2005) found that the social model principles and philosophies are effective in guiding treatment in aphasia.

These approaches and models are strongly reflective of the intervention goals identified by PWA. Both PWA and their family members identify increased life participation as a key area in which they would like to improve (Isaksen, 2014). A study by Worrall et al. (2011) found that the goals identified by PWA most often fell within the 'Activity and Participation' domain of the ICF framework (Kagan et al., 2008). A qualitative meta-analysis investigating 'living successfully with aphasia' identified participation in meaningful activities as fundamental by PWA, their families and speech-language therapists (Brown, Worrall, Davidson, \& Howe, 2012). Of concern is the finding that speech-language therapists continue to be anchored in traditional medical models of treatment of aphasia (Gauvreau, Le Dorze, Laliberté, \& Alary Gauvreau, 2016). Medical models place emphasis on the impairment, considering the causes of the condition and the specific changes to the structure of the body. Treatment will therefore focus primarily on isolated deficits. The risk of this model is treatment addressing underlying deficits, without considering participation 
and facilitation of new skills in everyday life (Hallowell, 2017). The importance of this is seen in a study conducted in Nigeria, where it was found that community reintegration is often poor in stroke survivors (Akosile et al., 2016). The researchers emphasise that particular attention must be given to mobility, vocational and social skills, two of which items fall within 'Activity and Participation' on the ICF (Akosile et al., 2016).

\subsection{Social participation in working-age adults}

In line with the development of these approaches and the subsequent drive towards their use in assessment and treatment, there appears to be increasing research into social participation and QOL of PWA (Dalemans et al., 2008; Hilari et al., 2012).

Research shows that individuals with stroke, both with and without aphasia, in young and middle adulthood face particular challenges to regain a meaningful level of involvement in society in their possible roles as providers, partners and parents, which older individuals may no longer be required to perform (R. J. P. Dalemans et al., 2008; Putaala et al., 2009). Furthermore, the stroke may contribute to a lifetime of medical complications, in addition to living an extended number of years with the effects of the stroke (Jacobs, Boden-Albala, Lin, \& Sacco, 2002).

While an increased interest in participation and QOL is evident, there seem to be a number of gaps in the literature. Hilari et al. (2012) found that there is limited research into HRQL for aphasia, with most studies focusing on the stroke population overall, with few researchers isolating PWA within the population (Northcott, Moss, Harrison, \& Hilari, 2016). In their comprehensive systematic review of articles published from 1970 to 2005 on social participation of PWA under the age of 65, Dalemans et al. (2008) identified a number of factors to consider. While it is clear that all the domains of social participation are affected in young PWA, the researchers advise caution in the interpretation of their findings (Dalemans et al., 2008). The review identified the need for an increase in the use of a clear conceptual framework and well-defined concepts in order to better interpret the literature (Dalemans et al., 2008). They found that many of the studies investigated included small sample sizes and a limited number of standardised assessments. The researchers were unable to identify studies describing community, civic and social life, one of the domains in 'Activity and Participation' of the ICF framework, as an 
important part of the studies. They note a lack of research into the impact of the environment on social participation and on return to work, which are key considerations in the working-age population. It is evident that much is still unknown about the participation of young and middle-aged adults with aphasia.

\subsection{Rationale}

The extensive review by Dalemans et al. (2008) included research studies until 2005, more than a decade past. When considering this time lapse, the clear recommendations of the authors for further research, as well as an increasing incidence of stroke in the young population, an update of recent publications and the quality thereof is required to inform current practice in speech-language therapy. With this knowledge, both assessment and treatment procedures can be adjusted to the unique needs of the working-age population for improved functional outcomes. These considerations lead to the research question: What is known about the impact of aphasia on social participation in working-age adults with stroke-related aphasia and what is the level of evidence of these studies from the last decade?

\subsection{Terminology as used in the dissertation}

\section{Social participation}

Social participation is defined as the 'actual performance of activities in social life domains in interactions with others in the context in which they live (R. J.P. Dalemans et al., 2008)'. 'Activity and Participation' is one of the domains identified on the ICF framework, along with Body Structure and Functions and Environmental and Personal factors (WHO, 2001). Participation refers to involvement in various life situations, which on the ICF includes a number of domains: domestic life, interpersonal relations and interactions, education and employment (major life areas) and community, civic and social life (WHO, 2001). An individual may experience certain participation restrictions as a result of a condition that is impacting on their body structure and function. The individual's participation in these domains is affected by contextual factors, including their environment and personal factors (WHO, 2001).

\section{Working-age adults}


Working-age adults have been defined as individuals from the age of 18 years (the average age of completion of secondary school) to 65 years of age, which is the common age of retirement. This period of time is one in which most individuals are engaged in some form of gainful employment. The purpose of this study is to investigate the impact of aphasia on this population that is still performing a wide variety of life roles, including bringing in an income. 


\section{CHAPTER 2}

\section{Aim of the chapter:}

The aim of this chapter is to state the purpose of the research study as well as to describe the design, study criteria and selection as well as the data extraction and risk of bias assessment procedures. This chapter elaborates on the methods used in the systematic review as the restrictions on the article length do not allow for comprehensive descriptions.

\subsection{Aim}

The aim of this research project is to provide an updated systematic review on the social participation of working-age adults with aphasia in the last decade (20052017), with emphasis on the level of evidence of the research included.

\subsection{Study design}

A systematic review was completed to investigate the proposed research question. Systematic reviews form the basis for developing practice guidelines and they provide information on gaps in the literature and therefore inform future research (Shamseer et al., 2015). Close attention was given to the level of evidence and risk of bias in each of the studies, as the strength of evidence on a specific topic determines whether intervention guidelines can be formulated with confidence. Dalemans et al. (2008) conducted a systematic review on social participation in the working-age population with aphasia, and included studies until 2005. The authors highlighted a number of gaps in the literature and the need for further research, particularly with more consistent use of a conceptual framework (R. J. P. Dalemans et al., 2008). With the development of the ICF framework in 2001, it was presumed that a greater number of studies in this field would make use of this framework, allowing for greater consistency in the concepts used as well as address domains of participation regarding which little is known. These factors highlighted the need for an updated systematic review including studies from 2005 to the present. The Preferred Reporting Items for Systematic Reviews and Meta-Analyses Protocols 
[PRISMA-P] (Shamseer et al., 2015) checklist was used to guide and structure the review (Appendix A). The PRISMA-P is a 27 numbered item checklist to guide protocol development of systematic reviews and meta-analyses evaluating therapeutic efficacy, however it is also recommended for any form of systematic review, qualitative or quantitative, because of the general lack of existing protocol guidance (Shamseer et al., 2015). The checklist contributed towards ensuring the comprehensiveness and transparency of this review on working-age adults with aphasia. As the study did not involve human participants directly, no institutional ethical clearance was required to conduct the research.

\subsection{Study inclusion criteria}

Articles pertaining to the various domains of social participation in working-age adults with aphasia were included in the study. The following electronic databases were searched, based on the relevance to the subject field and in line with item 10 on the PRISMA-P checklist: Scopus, PsychINFO and PubMed (Shamseer et al., 2015). The main search terms were: 'aphasia', and/or 'stroke', together with the following terms related to social participation according to the ICF (WHO, 2001) and A-FROM (Hallowell, 2017) frameworks: domestic life, relationships, education, employment, leisure, community life, social life, civic life. Additional search terms included 'quality of life', 'long-term outcomes', 'well-being' and 'self-esteem'. These same search terms used in the Dalemans et al. (2008) study were used to ensure comprehensiveness of the search as well as to provide comparable findings.

\subsection{Study selection}

A total of three searches were conducted across the three databases with the last search being run on 24/01/2017. Using this electronic search strategy (limited to 2005-2017, English only and only original articles and reviews), the initial search yielded 2,864 articles. The specified time limit was set as the review completed by Dalemans et al. (2008) only included studies until 2005. The eligibility criteria were developed according to item eight on the PRISMA-P checklist (Shamseer et al., 2015). An electronic software program, Covidence (https://www.covidence.org), was used in order to synthesise searches from the three databases as well as to identify duplicates and to review abstracts and full-text articles. Following the removal of 
duplicates, 1,625 articles remained. Systematic reviews were excluded to make use of only original studies. The identified articles' titles and abstracts were reviewed. Articles that discussed aphasia in conjunction with any of the identified social participation aspects or search terms were included for full-text review. Forty-one articles meeting the criteria were identified for full-text review.

A number of exclusion criteria were identified for the final review phase:

- Fewer than six PWA between the ages of 18 and 65

- This criterion was identified to eliminate single case studies and to ensure that the working-age population was sufficiently represented in the study. Case studies represent the lowest level of evidence on the American Speech-Language Hearing Association (ASHA) evidence rating scale (ASHA, 2004), and may not significantly contribute to a systematic review.

- The mean age of the aphasia participants was more than 65

- In an attempt for the research findings to reflect the performance of working-age adults, the mean age of the participants had to be below 65 years

- Quantitative studies in which the percentage of participants with aphasia was less than $10 \%$.

- This aspect was identified to ensure the aphasia population was adequately represented in the study.

- Participants with aphasia were not separately outlined in the study population characteristics.

- In order to determine whether the participants met the inclusion criteria, the PWA had to be separately described in order for studies to be comparable.

- PWA that were not stroke-related

- Studies in which aphasia was as a result of various conditions e.g. Traumatic Brain Injury were excluded to provide findings that were applicable to stroke-related aphasia and to ensure homogeneity of the study population.

- Participants presenting with aphasia after more than one stroke 
- An individual with more than one stroke may have different impairments from each incident. These impairments may influence findings in the assessment. The results may not purely be related to aphasia, but may be affected by a concomitant condition from a previous stroke.

- Only the acute phase (0-3 months) was reported on

- In the acute phase, PWA are frequently recovering medically and participating in intensive rehabilitation programs. In order to obtain a true reflection of the individual's social participation, he/she had to no longer be in the acute phase but rather have already returned home and be engaged in his/her daily life.

- The measurement instrument, methodology and/or statistical/qualitative analysis were not described

- It is not possible to compare studies or interpret the findings accurately if the instruments, methodology and data analysis are not well described.

- Spouses or carers described their own needs in relation to the PWA.

- While this is an interesting focus of research, the current study was investigating social participation of the PWA.

- QOL was measured by an assessment tool, but findings were not described in terms of social participation

- A number of studies investigated both QOL and HRQL of PWA. Many, however, simply measured these aspects using an assessment tool, but the findings were not described in terms of the domains of social participation, often simply obtaining a final score for each participant.

- Social participation aspects were not separately described in the study outcomes

- It is not possible to analyse study results if there is no specific discussion regarding one or more of the aspects that fall within the social participation domains.

- Changes in QOL or social participation following a treatment program or approach. 
- This aspect is again an interesting topic to investigate, however the aim of the current study was to describe social participation in relation to aphasia, and not the impact of various protocols on the participation of this group.

Two of the researchers independently reviewed the 41 articles. These articles included both quantitative and qualitative studies reporting on various aspects of social participation of working-age PWA. There were conflicting decisions on seven of the articles, and following discussion between the researchers, each item was resolved. Eleven articles were included in the final review (Figure 2).

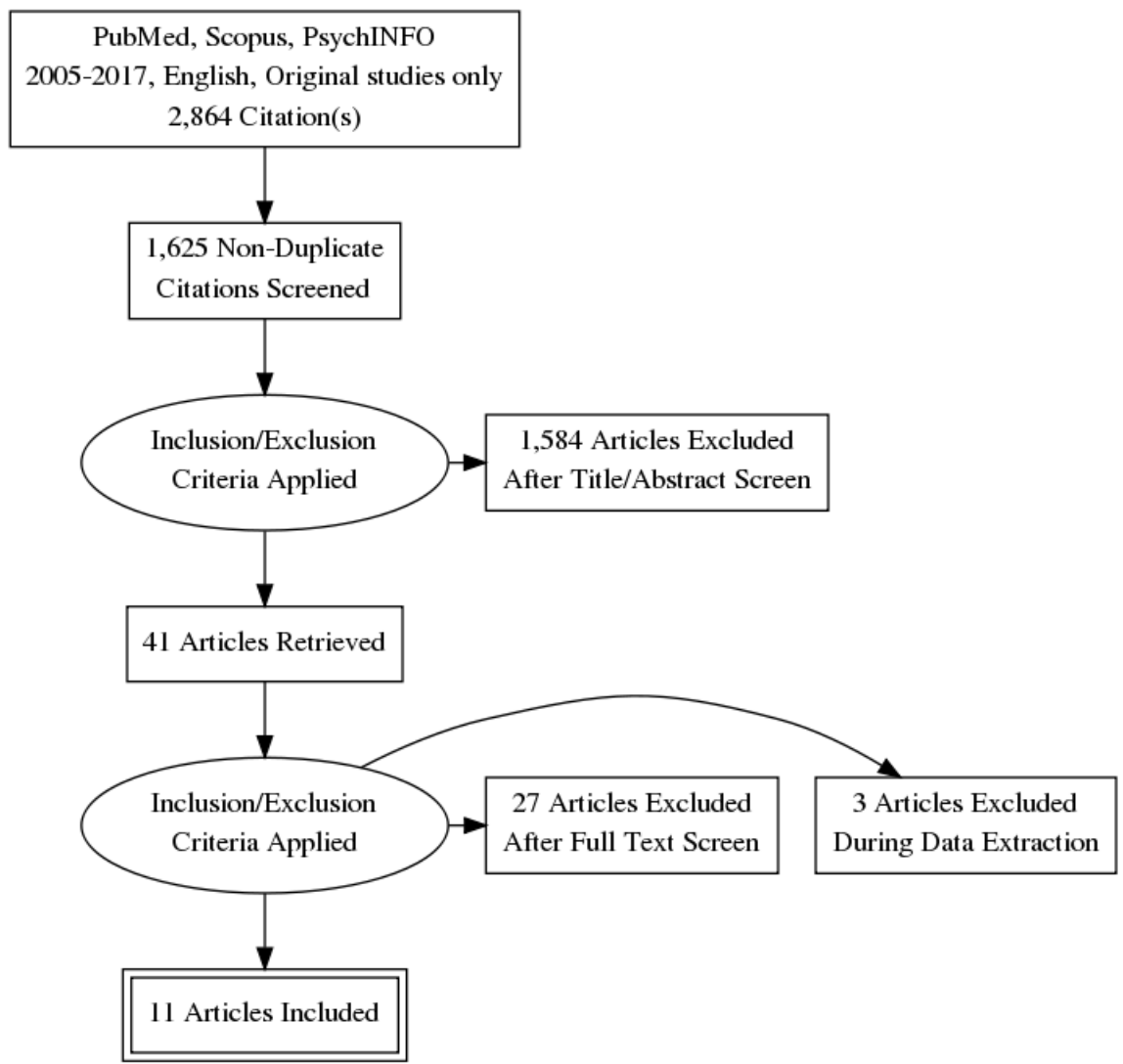

Figure 2. PRISMA flow chart of selection process

Table 1 provides a summary of the final selection of articles. Of these studies, five were qualitative in nature and six were quantitative. Six articles included aspects of domestic life, six investigated interpersonal relations and interactions and seven referred to education and employment. Only four articles included aspects of community, civic and social life and three referred to contextual factors impacting on social participation. Most of the studies were conducted in Europe, with the 
exception of two, one conducted in South Korea and another in Brazil. It appears that the majority of studies were completed in middle to high income countries (World Bank Group, 2017), which may have a greater number of resources to facilitate participation, with regards to the environment and education of the population. Social participation in developing or low income countries may be negatively affected by limitations in these same factors, which might lead one to tentatively conclude that PWA may experience greater barriers to social participation in low income countries. 
Table 1. Characteristics of included studies

\begin{tabular}{|c|c|c|c|c|c|c|}
\hline Author and year of publication & $\begin{array}{l}\text { Social participation } \\
\text { aspect/domain(s) studied }\end{array}$ & Q/QL & Country & Sampling method & $\begin{array}{l}\text { Mean age in } \\
\text { months (R/SD) }\end{array}$ & Sample size \\
\hline $\begin{array}{l}\text { Dalemans, De Witte, Wade, \& } \\
\text { Van den Heuvel (2010) }\end{array}$ & $\begin{array}{l}\text { Contextual factors impacting on } \\
\text { social participation }\end{array}$ & QL & Netherlands & $\begin{array}{l}\text { Purposive sampling, with criteria to include } \\
\text { different aphasia severities, genders, } \\
\text { levels of mobility and time post-onset }\end{array}$ & $\begin{array}{l}57,4 \\
\text { (R 45-71) }\end{array}$ & $\begin{array}{l}13 \text { PWA } \\
12 \text { Caregivers }\end{array}$ \\
\hline $\begin{array}{l}\text { Dalemans, De Witte, } \\
\text { Beurskens, Van den Heuvel, \& } \\
\text { Wade (2010) }\end{array}$ & $\begin{array}{l}\text { Domestic life, Education and } \\
\text { employment, Factors impacting on } \\
\text { social participation }\end{array}$ & $Q$ & Netherlands & Purposive sampling & $\begin{array}{l}64,2 \\
\text { (R 35-87) }\end{array}$ & 150 PWA \\
\hline Darrigrand et al. (2011) & $\begin{array}{l}\text { Domestic life, Factors impacting } \\
\text { on social participation }\end{array}$ & $Q$ & France & $\begin{array}{l}\text { Convenience sampling, part of a larger } \\
\text { study of stroke patients with aphasia }\end{array}$ & $\begin{array}{l}\text { Severe aphasia: } \\
63.7 \\
\text { (SD 15.1) } \\
\text { Moderate } \\
\text { aphasia: } 64.1 \\
\text { (SD 10.4) }\end{array}$ & $\begin{array}{l}27 \text { PWA (severe) } \\
9 \text { PWA (moderate) }\end{array}$ \\
\hline $\begin{array}{l}\text { Fotiadou, Northcott, } \\
\text { Chatzidaki, \& Hilari (2014) }\end{array}$ & $\begin{array}{l}\text { Interpersonal relations and } \\
\text { interactions, Education and } \\
\text { employment, Community, civic } \\
\text { and social life, Factors impacting } \\
\text { on social participation }\end{array}$ & QL & Greece & $\begin{array}{l}\text { Purposive sampling of blogs sustained by } \\
\text { a sole author who had aphasia following a } \\
\text { stroke, and which reflected on their social } \\
\text { network }\end{array}$ & $\begin{array}{l}48.8 \\
\text { (R 26-69) }\end{array}$ & 10 PWA \\
\hline Hilari \& Northcott (2006) & $\begin{array}{l}\text { Interpersonal relations and } \\
\text { interactions, Education and } \\
\text { employment }\end{array}$ & $Q$ & United Kingdom & Cluster sampling framework & $\begin{array}{l}61.6 \\
(R 21-92)\end{array}$ & 83 PWA \\
\hline $\begin{array}{l}\text { Łapkiewicz \& Grochmal-bach } \\
\text { (2008) }\end{array}$ & $\begin{array}{l}\text { Interpersonal relations and } \\
\text { interactions }\end{array}$ & QL & Poland & $\begin{array}{l}\text { Purposive sampling of married couples, } \\
\text { with one partner with severe aphasia }\end{array}$ & 58.7 & $\begin{array}{l}22 \text { PWA (and } \\
\text { partner) } \\
21 \text { Stroke, no } \\
\text { aphasia (and } \\
\text { partner) }\end{array}$ \\
\hline
\end{tabular}




\begin{tabular}{|c|c|c|c|c|c|c|}
\hline Lee, Lee, Choi, \& Pyun, (2015) & $\begin{array}{l}\text { Domestic activities, Education and } \\
\text { employment, Community, civic } \\
\text { and social life }\end{array}$ & Q & South Korea & $\begin{array}{l}\text { Convenience sampling of patients with } \\
\text { post-stroke aphasia ( } \geq 6 \text { months) }\end{array}$ & $\begin{array}{l}59.2 \\
(S D 7.2)\end{array}$ & $\begin{array}{l}2 \text { PWA } \\
42 \text { Control, no, } \\
\text { stroke, no aphasia }\end{array}$ \\
\hline Matos, Jesus, \& Cruice (2014) & $\begin{array}{l}\text { Domestic life, Interpersonal } \\
\text { relations and interactions, } \\
\text { Education and employment, } \\
\text { Community, civic and social life }\end{array}$ & QL & Portugal & Unclear & $\begin{array}{l}65 \\
\text { (R 41-80) }\end{array}$ & $\begin{array}{l}14 \text { PWA } \\
14 \text { Family members } \\
10 \mathrm{SLT}\end{array}$ \\
\hline $\begin{array}{l}\text { Mazaux, Lagadec, De Sèze, } \\
\text { Zongo, Asselineau, Douce, } \\
\text { Trias, Delair, Darrigrand } \\
\text { (2013) }\end{array}$ & Domestic life & Q & France & $\begin{array}{l}\text { Convenience sampling, part of a larger } \\
\text { study of stroke patients with aphasia }\end{array}$ & $\begin{array}{l}65.1 \\
(R \text { 13.5) }\end{array}$ & 100 PWA \\
\hline $\begin{array}{l}\text { Naess, Hammersvik, \& Skeie } \\
\text { (2009) }\end{array}$ & $\begin{array}{l}\text { Interpersonal relations and } \\
\text { interactions, Education and } \\
\text { employment }\end{array}$ & Q & Norway & $\begin{array}{l}\text { Purposive sampling from computer-based } \\
\text { hospital registries }\end{array}$ & $\begin{array}{l}42 \\
\text { (R 24-49) }\end{array}$ & $\begin{array}{l}20 \text { PWA } \\
175 \text { Control with } \\
\text { stroke, no aphasia }\end{array}$ \\
\hline $\begin{array}{l}\text { Pommerehn, Delboni, \& } \\
\text { Fedosse (2016) }\end{array}$ & $\begin{array}{l}\text { Domestic activities, Interpersonal } \\
\text { relations and interactions, } \\
\text { Community, civic and social life }\end{array}$ & QL & Brazil & $\begin{array}{l}\text { Convenience sampling from members of a } \\
\text { group }\end{array}$ & $\begin{array}{l}48.25 \\
\text { (R 25-67) }\end{array}$ & 12 PWA \\
\hline
\end{tabular}

Abbreviations: CVA: Cerebral Vascular Accident, NPO: Non-Profit Organisation, OT: Occupational Therapist, PWA: Person with Aphasia, Q: Quantitative, QL,

Qualitative, R; Range, SD: Standard deviation, SLT: Speech-language therapist 


\subsection{Data management and data items}

An electronic software program, Covidence, was used to synthesise searches from the three databases as well as to identify duplicates and to review abstracts and fulltext articles, in accordance with item 11a of the PRISMA-P checklist (Shamseer et al., 2015). Two of the researchers independently reviewed the articles identified for full-text review. There were conflicting decisions on seven of the identified articles, and following discussion amongst the researchers, each item was resolved. Each of the selected articles was reviewed and relevant data was extracted and compiled into summaries. Once a summarised table was developed and then divided into the four social participation domains, a second review of the extracted data was completed in order to ensure accuracy. The data items investigated are as follows (Item 12 on the PRISMA-P checklist):

1. Characteristics of the study, including title, author(s), year of publication, country where the study was conducted, type of study (qualitative or quantitative), sampling method, mean age, sample size, social participation domain investigated, measurements or instruments used as well as the assessment period post-stroke

2. The impact of aphasia on the four identified social participation domains according to the ICF framework, including domestic life, interpersonal life, education and employment and community, civic and social life.

\subsection{Risk of bias in selected studies}

An adapted version of the Newcastle-Ottawa Quality Assessment Scale [NOS] (Wells et al., 2014) was used (Appendix B). This 'star system' tool was developed to assess the quality of non-randomised studies ultimately for incorporating the assessments in the interpretation in systematic reviews (Wells et al., 2014). Each study was judged on three broad categories: study group selection; group comparability and outcomes with a greater number of stars indicating a higher level of evidence (Wells et al., 2014). The content validity and inter-rater reliability of this rating scale have been established (Wells et al., 2014). 
The widely accepted ASHA level of evidence rating scale was also used to categorise the selected studies (ASHA, 2004). This scale rates studies on four levels, with the lowest being IV and the highest being I (Table 2). Levels I and II are further differentiated into 'a' and 'b'. The rating scale aids in identifying studies of a higher level of evidence to contribute to accuracy in comparison of data from numerous studies. This evidence rating was independently completed by two of the researchers, and differences noted were resolved after discussion. 
Table 2. Quality assessment and level of evidence of selected studies

\begin{tabular}{|c|c|c|c|c|c|c|c|c|c|}
\hline \multirow[t]{2}{*}{ Source } & \multirow{2}{*}{$\begin{array}{l}\text { ASHA } \\
\text { level of } \\
\text { evidence }\end{array}$} & \multicolumn{4}{|c|}{$\begin{array}{c}\text { Selection } \\
\text { (Maximum } 5 \text { stars) }\end{array}$} & \multirow{2}{*}{$\begin{array}{l}\quad \begin{array}{l}\text { Comparability } \\
\text { (Maximum } 2 \text { stars) }\end{array} \\
\text { Comparability of } \\
\text { subjects in different } \\
\text { outcome groups on the } \\
\text { basis of design or } \\
\text { analysis. Confounding } \\
\text { factors controlled }\end{array}$} & \multicolumn{2}{|c|}{$\begin{array}{c}\text { Outcome } \\
\text { (Maximum } 3 \text { stars) }\end{array}$} & \multirow[t]{2}{*}{$\begin{array}{l}\text { Total } \\
\text { stars }\end{array}$} \\
\hline & & $\begin{array}{l}\text { Representative- } \\
\text { ness of the } \\
\text { sample }\end{array}$ & Sample size & $\begin{array}{l}\text { 1. Non-respondents } \\
\text { 2. Controls }\end{array}$ & $\begin{array}{l}\text { Ascertainment } \\
\text { of aphasia }\end{array}$ & & $\begin{array}{l}\text { 1. Assessmen } \\
\text { t of social } \\
\text { participatio } \\
\mathrm{n} \\
\text { 2. Same } \\
\text { method for } \\
\text { case and } \\
\text { control }\end{array}$ & Statistical test & \\
\hline $\begin{array}{l}\text { Mazaux et al. } \\
(2013)\end{array}$ & III & $\begin{array}{l}\text { (b) somewhat } \\
\text { representative of } \\
\text { the average in the } \\
\text { target population* }\end{array}$ & $\begin{array}{l}\text { (a) justified } \\
\text { and } \\
\text { appropriate* }\end{array}$ & $\begin{array}{l}\text { 1. (a) comparability } \\
\text { between respondents' } \\
\text { and non-respondents' } \\
\text { characteristics is } \\
\text { established and } \\
\text { satisfactory* } \\
\text { 2. no control }\end{array}$ & $\begin{array}{l}\text { (a) validated } \\
\text { measurement } \\
\text { tool on follow } \\
\text { up** }\end{array}$ & $\begin{array}{l}\text { (a) controlled for } \\
\text { aphasia* }^{*} \\
\text { (b) controlled for age, } \\
\text { language* }\end{array}$ & $\begin{array}{l}\text { 1. (c) self- } \\
\text { report } \\
\text { 2. N/A }\end{array}$ & $\begin{array}{l}\text { (a) clearly } \\
\text { described and } \\
\text { appropriate }^{*}\end{array}$ & $8 / 10$ \\
\hline $\begin{array}{l}\text { Dalemans, de } \\
\text { Witte, } \\
\text { Beurskens et } \\
\text { al. (2010) }\end{array}$ & III & $\begin{array}{l}\text { (b) somewhat } \\
\text { representative of } \\
\text { the average in the } \\
\text { target population* }\end{array}$ & $\begin{array}{l}\text { (a) justified } \\
\text { and } \\
\text { appropriate* }\end{array}$ & $\begin{array}{l}\text { 1. (a) comparability } \\
\text { between respondents' } \\
\text { and non-respondents' } \\
\text { characteristics is } \\
\text { established and } \\
\text { satisfactory* }^{*} \\
\text { 2. (b) hospital controls }\end{array}$ & $\begin{array}{l}\text { (a) screening } \\
\text { tool with } \\
\text { moderate } \\
\text { validity* }\end{array}$ & $\begin{array}{l}\text { (a) controlled for } \\
\text { aphasia* } \\
\text { (b) controlled for age, } \\
\text { time post stroke and } \\
\text { premorbid conditions* }\end{array}$ & $\begin{array}{l}\text { 1. (c) self- } \\
\text { report } \\
\text { 2. Yes }\end{array}$ & $\begin{array}{l}\text { (a) clearly } \\
\text { described and } \\
\text { appropriate }^{*}\end{array}$ & $7 / 10$ \\
\hline $\begin{array}{l}\text { Darrigrand et } \\
\text { al. (2011) }\end{array}$ & III & $\begin{array}{l}\text { (c) selected group } \\
\text { of participants }\end{array}$ & $\begin{array}{l}\text { (b) not } \\
\text { justified }\end{array}$ & $\begin{array}{l}\text { 1. (a) comparability } \\
\text { between respondents' } \\
\text { and non-respondents' } \\
\text { characteristics is } \\
\text { established and } \\
\text { satisfactory* } \\
\text { 2. (b) hospital control }\end{array}$ & $\begin{array}{l}\text { (a) validated } \\
\text { measurement } \\
\text { tool on follow } \\
\text { up** }\end{array}$ & $\begin{array}{l}\text { (a) controlled for } \\
\text { aphasia* } \\
\text { (b) controlled for age, } \\
\text { language* }\end{array}$ & $\begin{array}{l}\text { 1. (c) self- } \\
\text { report } \\
\text { 2. Yes }\end{array}$ & $\begin{array}{l}\text { (a) clearly } \\
\text { described and } \\
\text { appropriate* }^{*}\end{array}$ & $6 / 10$ \\
\hline
\end{tabular}




\begin{tabular}{|c|c|c|c|c|c|c|c|c|c|}
\hline $\begin{array}{l}\text { Hilari \& } \\
\text { Northcott } \\
\text { (2006) }\end{array}$ & III & $\begin{array}{l}\text { (b) somewhat } \\
\text { representative of } \\
\text { the average in the } \\
\text { target population* }\end{array}$ & $\begin{array}{l}\text { (a) justified } \\
\text { and } \\
\text { appropriate* }^{*}\end{array}$ & $\begin{array}{l}\text { 1. (b) comparability } \\
\text { between respondents } \\
\text { and non-respondents is } \\
\text { not satisfactory } \\
\text { 2. no control }\end{array}$ & $\begin{array}{l}\text { (a) screening } \\
\text { tool with } \\
\text { moderate } \\
\text { validity* }\end{array}$ & $\begin{array}{l}\text { (a) controlled for } \\
\text { aphasia* } \\
\text { (b) controlled for post- } \\
\text { stroke time period and } \\
\text { pre-morbid conditions }\end{array}$ & $\begin{array}{l}\text { 1. (c) self- } \\
\text { report } \\
\text { 2. N/A }\end{array}$ & $\begin{array}{l}\text { (a) clearly } \\
\text { described and } \\
\text { appropriate }^{\star}\end{array}$ & $6 / 10$ \\
\hline $\begin{array}{l}\text { Matos et al. } \\
\text { (2014) }\end{array}$ & III & $\begin{array}{l}\text { (c) selected group } \\
\text { of participants }\end{array}$ & $\begin{array}{l}\text { (b) not } \\
\text { justified }\end{array}$ & $\begin{array}{l}\text { 1. (a) comparability } \\
\text { between respondents' } \\
\text { and non-respondents' } \\
\text { characteristics is } \\
\text { established and } \\
\text { satisfactory* } \\
\text { 2. (c) No description }\end{array}$ & $\begin{array}{l}\text { (a) validated } \\
\text { measurement } \\
\text { tool }^{\star \star}\end{array}$ & $\begin{array}{l}\text { (a) controlled for } \\
\text { aphasia* } \\
\text { (b) controlled for age, } \\
\text { language, living place, } \\
\text { cognitive and hearing } \\
\text { functioning* }\end{array}$ & $\begin{array}{l}\text { 1. (b) self- } \\
\text { report } \\
\text { 2. N/A }\end{array}$ & $\begin{array}{l}\text { N/A } \\
\text { No statistical } \\
\text { test } \\
\text { conducted. } \\
\text { Qualitative } \\
\text { analysis } \\
\text { (Thematic } \\
\text { analysis based } \\
\text { on ICF) }\end{array}$ & $5 / 10$ \\
\hline $\begin{array}{l}\text { Naess et al. } \\
(2009)\end{array}$ & III & $\begin{array}{l}\text { (c) selected group } \\
\text { of participants }\end{array}$ & $\begin{array}{l}\text { (b) not } \\
\text { justified }\end{array}$ & $\begin{array}{l}\text { 1. (a) comparability } \\
\text { between respondents' } \\
\text { and non-respondents' } \\
\text { characteristics is } \\
\text { established and } \\
\text { satisfactory } \\
\text { 2. (b) hospital control }\end{array}$ & $\begin{array}{l}\text { (b) non- } \\
\text { validated } \\
\text { assessment } \\
\text { tool for } \\
\text { aphasia, but } \\
\text { the tool is } \\
\text { available* }\end{array}$ & $\begin{array}{l}\text { (a) controlled for } \\
\text { aphasia* } \\
\text { (b) controlled for age* }\end{array}$ & $\begin{array}{l}\text { 1. (c) self- } \\
\text { report } \\
\text { 2. Yes }\end{array}$ & $\begin{array}{l}\text { (a) clearly } \\
\text { described and } \\
\text { appropriate }^{*}\end{array}$ & $5 / 10$ \\
\hline $\begin{array}{l}\text { Łapkiewicz \& } \\
\text { Grochmal- } \\
\text { bach (2008) }\end{array}$ & III & $\begin{array}{l}\text { (c) selected group } \\
\text { of participants }\end{array}$ & $\begin{array}{l}\text { (b) not } \\
\text { justified }\end{array}$ & $\begin{array}{l}\text { 1. (c) no description of } \\
\text { the response rate or the } \\
\text { characteristics of the } \\
\text { responders and non- } \\
\text { responders } \\
\text { 2. (b) hospital control }\end{array}$ & $\begin{array}{l}\text { (a) validated } \\
\text { measurement } \\
\text { tool }^{\star \star}\end{array}$ & $\begin{array}{l}\text { (a) controlled for } \\
\text { aphasia* }^{*}\end{array}$ & $\begin{array}{l}\text { 1. (b) self- } \\
\text { report } \\
\text { 2. Yes }\end{array}$ & $\begin{array}{l}\text { (a) clearly } \\
\text { described and } \\
\text { appropriate* }^{*}\end{array}$ & $4 / 10$ \\
\hline $\begin{array}{l}\text { Lee et al. } \\
\text { (2015) }\end{array}$ & III & $\begin{array}{l}\text { (c) selected group } \\
\text { of participants }\end{array}$ & $\begin{array}{l}\text { (b) not } \\
\text { justified }\end{array}$ & $\begin{array}{l}\text { 1. (c) no description of } \\
\text { the response rate or the } \\
\text { characteristics of the } \\
\text { responders and non- } \\
\text { responders } \\
\text { 2. (b) hospital control }\end{array}$ & $\begin{array}{l}\text { (a) screening } \\
\text { tool with } \\
\text { moderate } \\
\text { validity* }\end{array}$ & $\begin{array}{l}\text { (a) controlled for } \\
\text { aphasia* } \\
\text { (b) controlled for } \\
\text { language, time post- } \\
\text { stroke, pre-morbid } \\
\text { conditions, functioning }\end{array}$ & $\begin{array}{l}\text { 1. (c) self- } \\
\text { report } \\
\text { 2. Yes }\end{array}$ & $\begin{array}{l}\text { (a) clearly } \\
\text { described and } \\
\text { appropriate* }^{*}\end{array}$ & $4 / 10$ \\
\hline
\end{tabular}




\begin{tabular}{|c|c|c|c|c|c|c|c|c|c|}
\hline & & & & & & at assessment ${ }^{*}$ & & & \\
\hline $\begin{array}{l}\text { Dalemans, de } \\
\text { Witte, Wade } \\
\text { et al. (2010) }\end{array}$ & III & $\begin{array}{l}\text { (c) selected group } \\
\text { of participants }\end{array}$ & $\begin{array}{l}\text { (b) not } \\
\text { justified }\end{array}$ & $\begin{array}{l}\text { 1. (b) comparability } \\
\text { between respondents } \\
\text { and non-respondents not } \\
\text { satisfactory } \\
\text { 2. (c) no control }\end{array}$ & $\begin{array}{l}\text { (a) screening } \\
\text { tool with } \\
\text { moderate } \\
\text { validity* }\end{array}$ & $\begin{array}{l}\text { (a) controlled for } \\
\text { aphasia* } \\
\text { (b) controlled for time } \\
\text { post-stroke, age, living } \\
\text { place, caregiver* }\end{array}$ & $\begin{array}{l}\text { 1. (c) self- } \\
\text { report } \\
\text { 2. N/A }\end{array}$ & $\begin{array}{l}\text { N/A } \\
\text { No statistical } \\
\text { analysis. } \\
\text { Qualitative } \\
\text { analysis with } \\
\text { use of an } \\
\text { online } \\
\text { software } \\
\text { program. } \\
\text { Description } \\
\text { fair. }\end{array}$ & $3 / 10$ \\
\hline $\begin{array}{l}\text { Fotiadou et al. } \\
\text { (2014) }\end{array}$ & III & $\begin{array}{l}\text { (c) selected group } \\
\text { of participants }\end{array}$ & $\begin{array}{l}\text { (b) not } \\
\text { justified }\end{array}$ & $\begin{array}{l}\text { 1. (a) comparability } \\
\text { between respondents' } \\
\text { and non-respondents' } \\
\text { characteristics is } \\
\text { established and } \\
\text { satisfactory* } \\
\text { 2. (c) no control }\end{array}$ & $\begin{array}{l}\text { (c) no } \\
\text { description of } \\
\text { a } \\
\text { measurement } \\
\text { tool }\end{array}$ & $\begin{array}{l}\text { (a) controlled for } \\
\text { aphasia* }^{*} \\
\text { (b) controlled for } \\
\text { language, age, content }{ }^{\star}\end{array}$ & $\begin{array}{l}\text { 1. (c) self- } \\
\text { report } \\
\text { 2. N/A }\end{array}$ & $\begin{array}{l}\text { N/A } \\
\text { No statistical } \\
\text { analysis. } \\
\text { Framework } \\
\text { analysis } \\
\text { completed. } \\
\text { Method of } \\
\text { analysis } \\
\text { qualitative and } \\
\text { well described }\end{array}$ & $3 / 10$ \\
\hline $\begin{array}{l}\text { Pommerehn } \\
\text { et al. (2016) }\end{array}$ & III & $\begin{array}{l}\text { (c) selected group } \\
\text { of participants }\end{array}$ & $\begin{array}{l}\text { (b) not } \\
\text { justified }\end{array}$ & $\begin{array}{l}\text { 1. (c) no description of } \\
\text { the response rate or the } \\
\text { characteristics of the } \\
\text { responders and non- } \\
\text { responders } \\
\text { 2. (c) no control }\end{array}$ & $\begin{array}{l}\text { (c) no } \\
\text { description of } \\
\text { the } \\
\text { measurement } \\
\text { tool }\end{array}$ & $\begin{array}{l}\text { (a) controlled for } \\
\text { aphasia* } \\
\text { (b) controlled for age, } \\
\text { participation in therapy* }\end{array}$ & $\begin{array}{l}\text { 1. (c) self- } \\
\text { report } \\
\text { 2. N/A }\end{array}$ & $\begin{array}{l}\text { N/A } \\
\text { No statistical } \\
\text { analysis. } \\
\text { Thematic } \\
\text { analysis based } \\
\text { on ICF. }\end{array}$ & $2 / 10$ \\
\hline
\end{tabular}


As evident in Table 2, all the studies were rated as Level III according to the ASHA rating scale, which is classified as 'well-designed, non-experimental studies'. On the NOS rating scale a wide range of levels of evidence were obtained, with the studies displayed from highest to lowest levels of evidence, and alphabetically where appropriate. For the purpose of interpretation, a score of $0-3 / 10$ was classified as a low level of evidence, a score of $4-6 / 10$ as a moderate level of evidence and $7-10 / 10$ as a high level of evidence. Two studies obtained a high level of evidence, six a moderate level of evidence and three a low level of evidence.

\subsection{Data analysis}

Thematic analysis was used to organise and synthesise the information obtained from the five qualitative and six quantitative studies, in accordance with the social participation domains identified in the ICF framework, namely domestic life, interpersonal relationships, education and employment, as well as community, civic and social life. Thematic analysis is a method used to interpret both implicit and explicit data items, requiring interpretation of the findings, which in this research study requires interpreting and synthesising the data into domains of social participation (Guest, MacQueen, \& Namey, 2012). The contextual factors impacting on social participation is an additional aspect identified in this review. This aspect was highlighted as an area for further research in the Dalemans et al. (2008) review and recent research has since been conducted on this topic.

Attention was given to the reliability and validity of the systematic review with the use of the latest guidelines and checklists. The PRISMA-P checklist provided detailed guidance on relevant information that must be included in the review, as well as the methods that should be followed to ensure a high degree of transparency in the study and allow replicability of the review (Shamseer et al., 2015). An adapted version of the NOS (Wells et al., 2014) was used to provide an objective representation of the quality of evidence of the selected studies. The article as submitted to 'Topics in Stroke Rehabilitation' is included in Chapter 3, with formatting and referencing as outlined by the journal editors. See Appendix C for proof of submission. 


\section{CHAPTER 3}

\section{Aim of the chapter:}

To present the systematic review article as submitted to Topics in Stroke Rehabilitation on 11/05/2017.

\subsection{Article}


Social participation in working-age adults with aphasia: An updated systematic review

Caitlin Pike, Alta Kritzinger, Bhavani Pillay

Department of Speech-Language Pathology and Audiology, University of Pretoria,

Pretoria, South Africa

Corresponding author: Caitlin Pike; University of Pretoria, Private Bag X20, Pretoria, Hatfield, 0028; 072326 1192; caitpike@ gmail.com

Co-author: Professor Alta Kritzinger; University of Pretoria, Private Bag X20, Pretoria, Hatfield, 0028; 012420 2949; alta.kritzinger@up.ac.za

Co-author: Bhavani Pillay; University of Pretoria, Private Bag X20, Pretoria, Hatfield, 0028; 012420 4919; bhavani.pillay@up.ac.za

The research was planned by all three authors, conducted by Caitlin Pike and the article written up by Caitlin Pike, Alta Kritzinger and Bhavani Pillay. 


\section{Social participation in working-age adults with aphasia: An updated systematic review}

Background: A previous systematic review found limited data regarding social participation in working-age people with aphasia (PWA). This population has many roles to fulfill, that are negatively affected by aphasia. A review of recent studies may reveal more information on challenges in re-establishing social roles and thus may inform treatment thereof.

Method: The aim was to provide an updated systematic review on social participation in PWA under 65 years of age. Studies from 2005-2017 were searched from Scopus, Pubmed and Psychinfo. Search terms were derived from the International Classification of Functioning, Disability and Health (ICF) and the Aphasia- Framework for Outcomes Measures (A-FROM). Aspects of domestic life, interpersonal relations and interactions, education and employment and community, civic and social life were investigated.

Results: From 2,864 initial hits, 11 studies were identified, all of which were on the American Speech-Language-Hearing Association (ASHA) Level III of evidence. The studies indicated that participation in domestic life is reduced and PWA showed reduced social networks, loss of friendships and changes in the quality of marital relations. Few PWA returned to work or spent time on education. Limitations in community, civic and social life were noted and there were contradictory findings on the impact of contextual factors on social participation. There was an increase in research into contextual factors impacting on social participation in PWA and in the use of conceptual frameworks in the last decade.

Conclusions: Social participation in working-age adults is limited across the social domains. While the ICF conceptual framework is increasingly used, no studies used the A-FROM. There is greater use of standardised assessments and larger sample sizes.

Keywords: stroke, aphasia; social participation, working-age, young, middleage, ICF

\section{Introduction}

There is an increase in stroke incidence between the ages of 20 and $54^{1}$. This is of concern as individuals with stroke in young and middle adulthood face particular 
challenges in regaining meaningful involvement in their roles as providers, partners and parents, which may no longer be required in later years ${ }^{2,3}$. Aphasia is one of the strongest predictors of poor functional recovery following a stroke ${ }^{4}$ and impacts on many facets of daily life.

A number of participation intervention approaches have been developed, the goal of which are to maximize re-engagement in daily life ${ }^{5,6}$. One approach, the Life Participation Approach to Aphasia [LPPA], emphasizes the concerns of the PWA within the treatment process ${ }^{7}$. Another, the World Health Organization International Classification of Functioning, Disability and Health $[\mathrm{WHO}-\mathrm{ICF}]^{7}$, helps to re-direct the focus to health, well-being and quality of life (QOL) ${ }^{7}$. An ICF compatible conceptual guide has been developed for aphasia: Living with Aphasia- Framework for Outcome Measurements $[\mathrm{A}-\mathrm{FROM}]^{8}$. This framework was developed to guide outcome measurements, with emphasis on real-life outcomes ${ }^{8}$.

These approaches are reflective of goals identified by PWA and their families. A key area in which PWA would like to improve is life participation ${ }^{9,10}$ and this aspect is highlighted as fundamental to living successfully with aphasia ${ }^{11}$. Of concern is the finding that SLTs continue to be anchored in traditional medical models of treatment ${ }^{12}$. Consistent with the development of and subsequent drive towards the use of these approaches, there appears to be increasing research into social participation or QOL of PWA ${ }^{2,13,14}$, however there appears to be limitations in the literature. In their systematic review (1960-2005) on social participation of PWA under 65 years, Dalemans et al. (2008) found that restrictions are evident across the social participation domains. The authors identified the need for increased use of a clear conceptual framework and well-defined concepts ${ }^{2}$. They found that many studies had small sample sizes and used few standardized assessments. The researchers were unable to identify 
studies describing community, civic and social life, one of the domains in "Activity and Participation" of the ICF, and they note a lack of research into the impact of the environment on social participation and return to work. It is evident that much is still unknown about the participation of working-age PWA.

When considering the dearth in literature, the increasing incidence in as well as the significant impact of aphasia on working-age adults, an expanded understanding of the social participation of these individuals is needed ${ }^{1-3,9,11}$. With this knowledge, assessment and treatment procedures can be adjusted to the unique needs of this population for improved functional outcomes. This leads to the research question: What is known about the impact of aphasia on social participation in working-age adults with stroke-related aphasia and what is the level of evidence of these studies from the last decade?

\section{Method}

\section{Study design}

A systematic review was completed according to the Preferred Reporting Items for Systematic Reviews and Meta-Analyses Protocols [PRISMA-P] ${ }^{15}$ checklist.

\section{Study inclusion criteria}

Three electronic databases were searched, based on relevance to the subject field: Scopus, PsychINFO and PubMed. The main search terms were: "aphasia", and/or "stroke", together with terms related to social participation according to the ICF and AFROM frameworks: domestic life, relationships, education, employment, leisure, community life, social life and civic life. Additional sterms included "quality of life", "long-term outcomes", "well-being" and "self-esteem". 


\section{Study selection}

Three searches were conducted with the last search being run on 24/01/2017. Using this electronic search strategy (limits: 2005-2017, English, original articles), the initial search yielded 2,864 articles. This time limit was set as the review completed by Dalemans et al. (2008) included studies until 2005. A software program, Covidence, was used to synthesize searches, identify duplicates and review articles. Following removal of duplicates, 1,625 articles remained. The articles' titles and abstracts were reviewed and articles that discussed aphasia in conjunction with an identified social participation aspect were included for full-text review. Forty-one articles met the criteria (Figure 1).

The following exclusion criteria were identified for the final review phase:

- Fewer than six PWA of 18 and 65 years, to eliminate single case studies which represent the lowest level of evidence on the American Speech-Language Hearing Association (ASHA) evidence rating scale ${ }^{16}$, and may not significantly contribute to a systematic review

- Percentage of PWA was less than $10 \%$ in quantitative studies

- Mean age of the PWA was more than 65

- PWA were not separately outlined in the population characteristics

- PWA were not stroke-related

- Participants presenting with aphasia after more than one stroke

- Only the acute phase (0-3 months) was reported on

- The measurement instrument, methodology and/or statistical/qualitative analysis were not described

- Spouses or carers described their own needs in relation to the PWA 
- QOL was measured, but findings were not described in terms of social participation

- Social participation aspects were not separately described in the study outcomes

- Social participation was discussed according to changes following a treatment program

\section{Data collection process and data items}

Data was extracted from the 11 selected articles and compiled into pre-developed tables. These tables were structured according to the ICF social participation domains, as initial article review indicated that this continues to be the predominant framework used, as opposed to the A-FROM. The data items investigated are as follows:

3. Characteristics of the study, including title, author(s), year of publication, country, type of study, sampling method, mean age, sample size, social participation domain investigated, measurements used and the assessment period post-stroke (Table 1)

4. The impact of aphasia on social participation domains: domestic life, interpersonal life, education and employment, community, civic and social life.

\section{Risk of bias in selected studies}

An adapted version of the Newcastle-Ottawa Quality Assessment Scale [NOS $]^{17}$ was used (Appendix B). This tool was developed to assess the quality of nonrandomised studies ${ }^{17}$. Each study was judged on three broad categories: study group selection, group comparability and outcomes with a greater number of stars indicating a higher level of evidence ${ }^{17}$. The content validity and inter-rater reliability of this rating scale have been established ${ }^{17}$. 
The widely accepted American Speech-Language-Hearing Association [ASHA] level of evidence rating scale were also used to categorise the selected studies (ASHA, 2004). This scale rates studies on four levels based on the research design used, with the lowest rating being IV and the highest being I (see Table 2). The ratings were independently completed by two of the researchers, and differences noted were resolved after discussion.

As evident in Table 2, all the studies were rated as Level III according to the ASHA rating scale, which is classified as 'well-designed, non-experimental studies'. On the NOS rating scale a wide range of levels of evidence were obtained, with the studies displayed from highest to lowest levels of evidence, and alphabetically, where appropriate. For the purpose of interpretation, a score of 0-3/10 stars was classified as a low level of evidence, a score of 4-6/10 stars as a moderate level of evidence and 710/10 stars as a high level of evidence. Two studies obtained a high level of evidence, six a moderate level of evidence and three a low level of evidence.

\section{Data analysis}

Thematic analysis was used to organize the data. This was done according to the social participation domains identified in the ICF. In addition, the contextual factors impacting on social participation were investigated.

\section{Results}

\section{Domestic life}

Domestic activities include social activities (e.g. shopping, home-making) and other secondary activities of daily living ${ }^{2}$. Studies that met the criteria were published from 2010 to 2016 (Table 3). The Echelle de Communication Verbale de Bordeaux (ECVB) was used in two studies that were part of a single cohort study and that were on 
moderate and high levels of evidence ${ }^{18,19}$. This questionnaire investigates communication activity in daily living. The factors identified as being the most challenging for working-age PWA in both studies were: using the phone, using checks and credit cards and communicating in social activities. Activity limitations in communication were more severe for individuals with severe aphasia than those with moderate aphasia ${ }^{19}$. Two studies ${ }^{20,21}$ used the Community Integration Questionnaire $(\mathrm{CIQ})^{22,23}$, a tool divided into three subscales: Home Integration, Productivity and Social Integration. The Home Integration subscale indicates the frequency of participating in activities such as shopping and housekeeping. Both studies, one on a moderate level and the other on a low level of evidence, found low scores in home integration. The final studies with low and moderate levels of evidence used a semistructured interview ${ }^{24}$, and the ICF checklist ${ }^{25}$. These studies found limitations in domestic tasks, with Pommerehn et al. (2016) identifying predominant difficulties in meal preparation, household chores, goods and services acquisition and helping others.

\section{Interpersonal relations and interactions}

This domain includes all formal and informal relationships ${ }^{2}$. This was investigated in six studies from 2006 to 2016 (Table 4). Two studies conducted analyses according to the $\mathrm{ICF}^{24,25}$. One used a social network questionnaire and the Medical Outcome Study Social Support Survey (MOS-SSS) ${ }^{26}$. The Dyadic Adjustment Scale (DAS) and Marital Communication Questionnaire (MCQ) were used in one study ${ }^{27}$ and another used the Communication Effectiveness Index $(\mathrm{CETI})^{28}$. The final study used a framework analysis of blog content ${ }^{29}$.

On a moderate level of evidence, significant differences between PWA and people with stroke, and no aphasia were found with regard to social isolation $(p=0.054$; Fisher exact $)^{28}$. Aphasia impacts on numerous relationships. In marriage, PWA identify 
a loss of harmony, satisfaction, cohesion, emotional expression and a loss in faith in the value of marriage ${ }^{27}$. The marital changes appear to be more extensive for PWA than for individuals with stroke, but no aphasia ${ }^{27}$. Interestingly, $86.3 \%$ of PWA found their relationships with their children were maintained or improved following the stroke, and $75.4 \%$ of PWA reported this to be true for relations with other relatives ${ }^{26}$. A number of the identified studies, on a moderate to low level of evidence, indicated a reduction in social networks of PWA, particularly friendships ${ }^{24-26,29}$. Studies with a low level of evidence note limitations in all relations ${ }^{25}$ and found particular challenges with in-depth conversations and participation in family activities ${ }^{29}$. PWA experienced a higher degree of dependence and changes in the roles they played ${ }^{29}$.

\section{Education and employment}

Education includes informal, vocational training and higher education, while employment consists of informal, remunerative and non-remunerative employment, excluding domestic work ${ }^{2}$. These seven studies (2006-2016) are reflected in Table 5. Two studies on a moderate to high level of evidence used the Productivity subscale of the CIQ, with both finding limitations in productivity ${ }^{20,21}$. Attention was given to return to work $^{13,24,28,29}$ and the ability to participate in work activities ${ }^{24,25}$. Overall, the studies indicated a greatly reduced productivity level, with few working-age participants returning to paid employment. In a study on a moderate level of evidence, it was found that PWA spent less time on education than individuals without aphasia ${ }^{20}$. The data from an additional study with a low level of evidence indicated that five out of twelve PWA noted moderate or severe limitations in informal education ${ }^{25}$.

\section{Community, civic and social life}

This includes leisure and recreational activities ${ }^{2}$. The four studies (2010-2016) are 
shown in Table 6. In two studies with moderate and high levels of evidence respectively, the Social Integration subscale of the CIQ was used ${ }^{20,21}$, which indicated reduced social integration in working-age PWA, with a decrease in time spent on leisure activities $^{20}$. The remaining two studies on moderate and low levels of evidence respectively, used the ICF to report on their findings ${ }^{24,29}$. Of the aspects investigated, restrictions in recreation and leisure activities were noted. Restrictions in community life, political life and citizenship were also found ${ }^{25}$.

\section{Contextual factors}

Three studies (2010-2016) investigated contextual factors impacting on social participation of PWA ${ }^{21,25,30}$ (Table 7).

A number of personal factors were identified to impact on participation in young PWA: motivation, physical and psychological condition and communication skills ${ }^{30}$. Environmental factors found to impact the PWA were the role of the central caregiver, characteristics of the communication partners (willingness, skills, knowledge) and quietness and familiarity of the living place ${ }^{30}$. The support of individuals with whom the PWA lives had a positive impact on social participation ${ }^{30}$. Furthermore, PWA found additional barriers to social participation to be services, systems and re-integration policies in employment ${ }^{25}$. These personal and environmental factors were identified in two low level of evidence studies. Contrastingly, in a study with a high evidence rating, contextual factors were not significantly associated with social participation in $\operatorname{aphasia~}^{21}$

\section{Discussion}

\section{Main findings}

A systematic review was completed to investigate social participation in four life 
domains (domestic activities, interpersonal relations and interactions, education and employment and community, civic and social life) in working-age adults (18-65 years) with aphasia. Eleven articles were identified to be pertinent to the topic.

There appears to be limitations in the knowledge regarding the social participation of this population. Overall, it is evident that social participation across the four domains is greatly reduced for young PWA.

Domestic life has been relatively well researched, with varied concepts investigated. Three assessment tools/frameworks were used, namely the ICF, CIQ and the ECVB. Of those studies using the ICF, one mapped the participants' responses onto the framework, with findings focused largely on household tasks, while the other study included a checklist that investigated a number of concepts (e.g. acquisition of goods and services, preparing meals). The CIQ investigates concepts such as preparing meals, housework and caring for children and the ECVB investigates concepts such as conversing with family members, making phone calls and using a credit card, from a more communicative perspective. While certain items overlap, the concepts assessed are varied and are reflective of the ICF. It is evident that domestic life for young individuals is negatively impacted by aphasia. This finding is in agreement with those found by Dalemans et al. (2008) in their systematic review. Dalemans et al. (2008) found nine studies in this domain and the current study identified six, however a greater percentage of the studies in the current review made use of standardized assessments. Interpersonal relations and interactions in PWA are affected, with PWA reporting a reduction in the number of people within their social network, with particular loss of friendships, and negative changes in the quality of their marital relationships. Two of the six studies were analyzed according to the ICF, with consensus across the studies regarding the negative impact of aphasia on this life 
domain. Although a wide variety of concepts were investigated, the findings are reflective of those found by Dalemans et al. (2008).

A number of studies investigated education and employment, with two studies using the ICF. Two studies used the Productivity subscale of the CIQ, which investigated work, training and volunteer programs and is well-reflective of the ICF. The remaining studies used interview formats or patient history reviews. Few PWA returned to work and many reported changes in their ability to participate in work tasks/productive activity. Two studies made mention of education, reporting that PWA spent less time on education than individuals without stroke and that some PWA felt moderate to severe limitations in their ability to participate in educational-type activities. The attention to education appears to be a new avenue of research in PWA, as Dalemans et al. (2008) did not identify findings on this topic in their review.

The domain with the most limited research was that of community, civic and social life. Two studies reported on the Social Integration domain of the CIQ, which investigates items such as going out and leisure activities. Both studies found limitations in social integration, which was also noted by a study analyzing interview findings of participants according to the ICF. Dalemans et al. (2008) found similar results in leisure activities, but were unable to identify research on the remaining aspects of this domain. In the current review, only one study commented on all aspects of this domain (community life, recreation and leisure, religion and spirituality, political life and citizenship). It appears that PWA found greatest limitations in community life, followed by recreation and leisure and political life and citizenship. Few individuals found limitations in religion and spirituality.

An area of more recent research is the impact of contextual factors on social participation in PWA. While one study did not find that contextual factors impact on 
social participation, the remaining two studies did, with a key environmental factor in both studies being the support of the central caregiver of the PWA.

The current review is in agreement with many of the findings reported in Dalemans et al. (2008). Of interest is the attention given to items identified as limitations or areas for further research. The researchers of the previous review indicated the need for increased use of a conceptual framework. It is evident that the ICF is becoming more widely used, which may enable more comparable results, however, the use is still fairly limited. It was noted that the A-FROM is not being used in research in this population. As this framework was developed in 2008, it would be expected that it would be more frequently used in recent years. Dalemans et al. (2008) also identified the need for research into the environmental factors impacting on social participation, and although limited, there is increasing research into this aspect. Two studies included comparison of social participation in stroke PWA, to stroke participants without aphasia, which was identified as a component for further research ${ }^{2}$. While a number of self-developed questionnaires were used in the studies included in this review, there appears to be an increased trend towards using more standardized assessment measures. An encouraging factor is the apparent larger sample sizes in the included studies, which contributes to the reliability and generalizability of the findings. It appears that this rising population of young PWA is receiving increasing attention.

\section{Study limitations}

While the use of a conceptual framework is more evident than in the Dalemans et al. (2008) review, there were a number of studies in which the concept of participation was not well defined, which limited data synthesis. There still appears to be limited research focusing exclusively on working-age PWA. While a mean age limit of 65 was set, and the younger population is highlighted with this criterion, it is not possible to set a clear 
distinction between the young and old population of PWA as yet. While every effort has been made to identify all studies related to social participation, limitations in search terms and the databases selected may have resulted in pertinent studies not being included.

\section{Future research}

While there is increased use of the ICF in studies, additional research is warranted to allow a more in-depth understanding of social participation, with a clear conceptual framework (ICF or A-FROM). The research on the impact of contextual factors on social participation appears limited and contradictory. All the studies included in the review were conducted in high-income countries, with the exception of one conducted in Brazil, which is an upper-middle income country ${ }^{31}$. Social participation is likely to be influenced by contextual factors, such as a county's per capita income. It is clear that studies from low to middle income countries is largely missing from existing data. While a few studies compare the social participation of young PWA to young adults with stroke, and no aphasia, this requires additional investigation.

\section{Conclusion}

Working-age PWA experience limitations across social participation domains. There is contradictory information regarding the impact of contextual on social participation in PWA, although a number of factors have been identified. The ICF is being used more frequently to guide research studies in social participation, but there is still a lack of consistency in the use of concepts, and to a certain extent, standardized assessment tools. These factors lead one to interpret the findings with caution. 


\section{Geolocation information}

This systematic review was conducted in Pretoria, South Africa.

\section{Acknowledgements}

\section{Competing interests}

The authors declare that they have no financial or personal relationships that may have inappropriately influenced them in the writing of the article.

\section{Authors' contributions}

C.P. (University of Pretoria) main researcher. C.P. (University of Pretoria), A.K.

(University of Pretoria) and B.P. (University of Pretoria) planned the research and wrote the article.

\section{References}

1. Kissela BM, Khoury JC, Alwell K, et al. Age at stroke: temporal trends in stroke incidence in a large, biracial population. Neurology. 2012;79(17):1781-1787. doi:10.1212/WNL.0b013e318270401d.

2. Dalemans RJP, De Witte LP, Wade DT, Van den Heuvel WJA. A description of social participation in working-age persons with aphasia: a review of the literature. Aphasiology. 2008;22(10):1071-1091. doi:10.1080/02687030701632179.

3. Putaala J, Metso AJ, Metso TM, et al. Analysis of 1008 consecutive patients aged 15 to 49 with first-ever ischemic stroke: the Helsinki young stroke registry. Stroke. 2009;40(4):1195-1203. doi:10.1161/STROKEAHA.108.529883.

4. Fang Y, Chen X, Li H, Lin J, Huang R, Zeng J. A study on additional early physiotherapy after stroke and factors affecting functional recovery. Clin 
Rehabil. 2003;17:608-617. doi:10.1191/0269215503cr655oa.

5. Kagan A, Simmons-Mackie N. Beginning with the end: outcome-driven assessment and intervention with life participation in mind. Top Lang Disord. 2007;27(4):309-317.

6. Roth FP, Worthington CK. Treatment Resource Manual for Speech-Language Pathology. 3rd ed. Clifton Park: Thomson Delmar Learning; 2005.

7. Hallowell B. Aphasia and Other Acquired Neurogenic Language Disorders. San Diego: Plural Publishing. Pre-publication release; 2017.

8. Kagan A, Simmons-Mackie N, Rowland A, et al. Counting what counts: a framework for capturing real-life outcomes of aphasia intervention. Aphasiology. 2008;22(3):258-280. doi:10.1080/02687030701282595.

9. Worrall L, Sherratt S, Rogers P, et al. What people with aphasia want: their goals according to the ICF. Aphasiology. 2011;25(3):309-322. doi:10.1080/02687038.2010.508530.

10. Isaksen JK. It really makes good sense: the role of outcome evaluation in aphasia therapy in Denmark. Int J Lang Commun Disord. 2014;49(1):90-99. doi:10.1111/1460-6984.12049.

11. Brown K, Worrall LE, Davidson B, Howe T. Living successfully with aphasia: a qualitative meta-analysis of the perspectives of individuals with aphasia, family members, and speech-language pathologists. Int J Speech Lang Pathol. 2012;14(2):141-155. doi:10.3109/17549507.2011.632026.

12. Gauvreau CA, Le Dorze G, Laliberté M-P, Alary Gauvreau C. A pilot study on 
how speech-language pathologists include social participation in aphasia rehabilitation. Aphasiology. 2016;30(10):1117-1133.

doi:10.1080/02687038.2015.1100708.

13. Hilari K, Needle JJ, Harrison KL. What are the important factors in health-related quality of life for people with aphasia? A systematic review. Arch Phys Med Rehabil. 2012;93(1 SUPPL.):S86-S95.e4. doi:10.1016/j.apmr.2011.05.028.

14. Graham JR, Pereira S, Teasell R. Aphasia and return to work in younger stroke survivors. Aphasiology. 2011;25(8):952-960.

doi:10.1080/02687038.2011.563861.

15. Shamseer L, Moher D, Clarke M, et al. Preferred reporting items for systematic review and meta-analysis protocols (PRISMA-P) 2015: elaboration and explanation. BMJ. 2015;349(3):g7647. doi:10.1136/bmj.g7647.

16. American Speech-Language-Hearing Association [ASHA]. Evidence-Based Practice in Communication Disorders: An Introduction. Rockville; 2004.

17. Wells GA, Shea B, O'Connell D, et al. The Newcastle-Ottawa Scale (NOS) for assessing the quality of nonrandomised studies in meta-analyses. http://www.ohri.ca/programs/clinical_epidemiology/oxford.asp. Published 2014. Accessed March 30, 2017.

18. Mazaux JM, Lagadec T, De Sèze MP, et al. Communication activity in stroke patients with aphasia. J Rehabil Med. 2013;45(4):341-346. doi:10.2340/16501977-1122.

19. Darrigrand B, Dutheil S, Michelet V, Rereau S, Rousseaux M, Mazaux J-M. 
Communication impairment and activity limitation in stroke patients with severe aphasia. Disabil Rehabil. 2011;33(13-14):1169-1178.

doi:10.3109/09638288.2010.524271.

20. Lee H, Lee Y, Choi H, Pyun SB. Community integration and quality of life in aphasia after stroke. Yonsei Med J. 2015;56(6):1694-1702.

doi:10.3349/ymj.2015.56.6.1694.

21. Dalemans RJP, De Witte LP, Beurskens AJHM, Van den Heuvel WJA, Wade DT. An investigation into the social participation of stroke survivors with aphasia. Disabil Rehabil. 2010;32(20):1678-1685. doi:10.3109/09638281003649938.

22. Willer B, Ottenbacher KJ, Coad ML. The Community Integration Questionnaire: a comparitive examination. Am J Phys Med Rehabil. 1994;73:103-111.

23. Dalemans RJ, De Witte LP, Beurskens AJ, Van den Heuvel WJ, Wade DT. Psychometric Properties of the Community Integration Questionnaire Adjusted for People With Aphasia. Arch Phys Med Rehabil. 2010;91(3):395-399. doi:10.1016/j.apmr.2009.10.021.

24. Matos MA, Jesus LMT, Cruice M. Consequences of stroke and aphasia according to the ICF domains: views of Portuguese people with aphasia, family members and professionals. Aphasiology. 2014;28(7):771-796.

25. Pommerehn J, Delboni MCC, Fedosse E. International Classification of Functioning, Disability and Health, and aphasia: a study of social participation. CoDAS. 2016;28(2):132-140. doi:10.1590/2317-1782/201620150102. 
26. Hilari K, Northcott S. Social support in people with chronic aphasia. Aphasiology. 2006;20(1):17-36. doi:10.1080/02687030500279982.

27. Łapkiewicz E, Grochmal-Bach B. Aphasia and changes in the quality of marital relations. Neuropsychologica. 2008;6(3):237-246.

28. Naess H, Hammersvik L, Skeie GO. Aphasia among young patients with ischemic stroke on long-term follow-up. J Stroke Cerebrovasc Dis. 2009;18(4):247-250. doi:10.1016/j.jstrokecerebrovasdis.2008.10.005.

29. Fotiadou D, Northcott S, Chatzidaki A, Hilari K. Aphasia blog talk: how does stroke and aphasia affect the carer and their relationship with the person with aphasia? Aphasiology. 2014;28(11):1301-1319.

doi:10.1080/02687038.2014.928665.

30. Dalemans RJP, De Witte LP, Wade DT, Van den Heuvel WJA. Social participation through the eyes of people with aphasia. Int J Lang Commun Disord. 2010;45(5):537-550. doi:10.3109/13682820903223633.

31. World Bank Group. World Bank country and lending groups- country classification. https://datahelpdesk.worldbank.org/knowledgebase/articles/906519-world-bankcountry-and-lending-groups. Published 2017. Accessed May 11, 2017. 
Table 1. Characteristics of included studies $(n=11)$

\begin{tabular}{|c|c|c|c|c|c|c|}
\hline Author and year of publication & $\begin{array}{l}\text { Social participation } \\
\text { aspect/domain(s) studied }\end{array}$ & $\mathrm{Q} / \mathrm{QL}$ & Country & Sampling method & $\begin{array}{l}\text { Mean age in } \\
\text { months (R/SD) }\end{array}$ & Sample size \\
\hline $\begin{array}{l}\text { Dalemans, De Witte, Wade, \& } \\
\text { Van den Heuvel (2010) }\end{array}$ & $\begin{array}{l}\text { Contextual factors impacting on } \\
\text { social participation }\end{array}$ & QL & Netherlands & $\begin{array}{l}\text { Purposive sampling, with criteria to } \\
\text { include different aphasia severities, } \\
\text { genders, levels of mobility and time post- } \\
\text { onset }\end{array}$ & $\begin{array}{l}57,4 \\
(\mathrm{R} 45-71)\end{array}$ & $\begin{array}{l}13 \text { PWA } \\
12 \text { Caregivers }\end{array}$ \\
\hline $\begin{array}{l}\text { Dalemans, De Witte, } \\
\text { Beurskens, Van den Heuvel, } \\
\& \text { Wade (2010) }\end{array}$ & $\begin{array}{l}\text { Domestic life, Education and } \\
\text { employment, Factors impacting } \\
\text { on social participation }\end{array}$ & $\mathrm{Q}$ & Netherlands & Purposive sampling & $\begin{array}{l}64,2 \\
\text { (R 35-87) }\end{array}$ & 150 PWA \\
\hline Darrigrand et al. (2011) & $\begin{array}{l}\text { Domestic life, Factors impacting } \\
\text { on social participation }\end{array}$ & $\mathrm{Q}$ & France & $\begin{array}{l}\text { Convenience sampling, part of a larger } \\
\text { study of stroke patients with aphasia }\end{array}$ & $\begin{array}{l}\text { Severe aphasia: } \\
63.7 \\
\text { (SD 15.1) } \\
\text { Moderate } \\
\text { aphasia: } 64.1 \\
\text { (SD 10.4) }\end{array}$ & $\begin{array}{l}27 \text { PWA (severe) } \\
9 \text { PWA (moderate) }\end{array}$ \\
\hline $\begin{array}{l}\text { Fotiadou, Northcott, } \\
\text { Chatzidaki, \& Hilari (2014) }\end{array}$ & $\begin{array}{l}\text { Interpersonal relations and } \\
\text { interactions, Education and } \\
\text { employment, Community, civic } \\
\text { and social life, Factors impacting } \\
\text { on social participation }\end{array}$ & QL & Greece & $\begin{array}{l}\text { Purposive sampling of blogs sustained by } \\
\text { a sole author who had aphasia following a } \\
\text { stroke, and which reflected on their social } \\
\text { network }\end{array}$ & $\begin{array}{l}48.8 \\
(\mathrm{R} 26-69)\end{array}$ & $10 \mathrm{PWA}$ \\
\hline Hilari \& Northcott (2006) & $\begin{array}{l}\text { Interpersonal relations and } \\
\text { interactions, Education and } \\
\text { employment }\end{array}$ & $\mathrm{Q}$ & United Kingdom & Cluster sampling framework & $\begin{array}{l}61.6 \\
\text { (R 21-92) }\end{array}$ & $83 \mathrm{PWA}$ \\
\hline $\begin{array}{l}\text { Eapkiewicz \& Grochmal-bach } \\
\text { (2008) }\end{array}$ & $\begin{array}{l}\text { Interpersonal relations and } \\
\text { interactions }\end{array}$ & $\mathrm{QL}$ & Poland & $\begin{array}{l}\text { Purposive sampling of married couples, } \\
\text { with one partner with severe aphasia }\end{array}$ & 58.7 & $\begin{array}{l}22 \text { PWA (and } \\
\text { partner) } \\
21 \text { Stroke, no } \\
\text { aphasia (and } \\
\text { partner) }\end{array}$ \\
\hline $\begin{array}{l}\text { Lee, Lee, Choi, \& Pyun, } \\
\text { (2015) }\end{array}$ & $\begin{array}{l}\text { Domestic activities, Education } \\
\text { and employment, Community, }\end{array}$ & Q & South Korea & $\begin{array}{l}\text { Convenience sampling of patients with } \\
\text { post-stroke aphasia ( } \geq 6 \text { months) }\end{array}$ & $\begin{array}{l}59.2 \\
(\text { SD } 7.2)\end{array}$ & $\begin{array}{l}32 \text { PWA } \\
42 \text { Control, no, }\end{array}$ \\
\hline
\end{tabular}




\begin{tabular}{|c|c|c|c|c|c|c|}
\hline & civic and social life & & & & & stroke, no aphasia \\
\hline Matos, Jesus, \& Cruice (2014) & $\begin{array}{l}\text { Domestic life, Interpersonal } \\
\text { relations and interactions, } \\
\text { Education and employment, } \\
\text { Community, civic and social life }\end{array}$ & QL & Portugal & Unclear & $\begin{array}{l}65 \\
(\mathrm{R} 41-80)\end{array}$ & $\begin{array}{l}14 \text { PWA } \\
14 \text { Family members } \\
10 \text { SLT }\end{array}$ \\
\hline $\begin{array}{l}\text { Mazaux, Lagadec, De Sèze, } \\
\text { Zongo, Asselineau, Douce, } \\
\text { Trias, Delair, Darrigrand } \\
\text { (2013) }\end{array}$ & Domestic life & Q & France & $\begin{array}{l}\text { Convenience sampling, part of a larger } \\
\text { study of stroke patients with aphasia }\end{array}$ & $\begin{array}{l}65.1 \\
(\mathrm{R} 13.5)\end{array}$ & 100 PWA \\
\hline $\begin{array}{l}\text { Naess, Hammersvik, \& Skeie } \\
\text { (2009) }\end{array}$ & $\begin{array}{l}\text { Interpersonal relations and } \\
\text { interactions, Education and } \\
\text { employment }\end{array}$ & Q & Norway & $\begin{array}{l}\text { Purposive sampling from computer-based } \\
\text { hospital registries }\end{array}$ & $\begin{array}{l}42 \\
\text { (R 24-49) }\end{array}$ & $\begin{array}{l}20 \text { PWA } \\
175 \text { Control with } \\
\text { stroke, no aphasia }\end{array}$ \\
\hline $\begin{array}{l}\text { Pommerehn, Delboni, \& } \\
\text { Fedosse (2016) }\end{array}$ & $\begin{array}{l}\text { Domestic activities, Interpersonal } \\
\text { relations and interactions, } \\
\text { Community, civic and social life }\end{array}$ & QL & Brazil & $\begin{array}{l}\text { Convenience sampling from members of } \\
\text { a group }\end{array}$ & $\begin{array}{l}48.25 \\
\text { (R 25-67) }\end{array}$ & 12 PWA \\
\hline
\end{tabular}

Abbreviations: CVA: Cerebral Vascular Accident, NPO: Non-Profit Organisation, OT: Occupational Therapist, PWA: Person with Aphasia, Q: Quantitative, QL; Qualitative,

R; Range, SD: Standard deviation, SLT: Speech-language therapist 
Table 2. Quality assessment and level of evidence of selected studies

\begin{tabular}{|c|c|c|c|c|c|c|c|c|c|}
\hline \multirow[t]{2}{*}{ Source } & \multirow{2}{*}{$\begin{array}{l}\text { ASHA } \\
\text { level of } \\
\text { evidence }\end{array}$} & \multicolumn{4}{|c|}{$\begin{array}{c}\text { Selection } \\
\text { (Maximum } 5 \text { stars) }\end{array}$} & \multirow{2}{*}{\begin{tabular}{l}
$\begin{array}{c}\text { Comparability } \\
\text { (Maximum } 2\end{array}$ \\
\multicolumn{1}{c}{$\quad$ stars) } \\
Comparability of \\
subjects in \\
different \\
outcome groups \\
on the basis of \\
design or \\
analysis. \\
Confounding \\
factors controlled
\end{tabular}} & \multicolumn{2}{|c|}{$\begin{array}{c}\text { Outcome } \\
\text { (Maximum } 3 \text { stars) }\end{array}$} & \multirow[t]{2}{*}{$\begin{array}{l}\text { Total } \\
\text { stars }\end{array}$} \\
\hline & & $\begin{array}{l}\text { Representative- } \\
\text { ness of the } \\
\text { sample }\end{array}$ & Sample size & $\begin{array}{l}\text { 3. Non- } \\
\text { respondents } \\
\text { 4. Controls }\end{array}$ & $\begin{array}{l}\text { Ascertainment of } \\
\text { aphasia }\end{array}$ & & $\begin{array}{l}\text { 3. Assessment of } \\
\text { social } \\
\text { participation } \\
\text { 4. Same method } \\
\text { for case and } \\
\text { control }\end{array}$ & Statistical test & \\
\hline $\begin{array}{l}\text { Mazaux et al. } \\
\text { (2013) }\end{array}$ & III & $\begin{array}{l}\text { (b) somewhat } \\
\text { representative of } \\
\text { the average in } \\
\text { the target } \\
\text { population* }\end{array}$ & $\begin{array}{l}\text { (a) justified and } \\
\text { appropriate* }\end{array}$ & $\begin{array}{l}\text { 1. (a) } \\
\text { comparability } \\
\text { between } \\
\text { respondents' and } \\
\text { non-respondents' } \\
\text { characteristics is } \\
\text { established and } \\
\text { satisfactory* } \\
\text { 2. no control }\end{array}$ & $\begin{array}{l}\text { (a) validated } \\
\text { measurement } \\
\text { tool on follow } \\
\text { up** }\end{array}$ & $\begin{array}{l}\text { (a) controlled for } \\
\text { aphasia* } \\
\text { (b) controlled for } \\
\text { age, language* }\end{array}$ & $\begin{array}{l}\text { 1. (c) self-report } \\
\text { 2. N/A }\end{array}$ & $\begin{array}{l}\text { (a) clearly } \\
\text { described and } \\
\text { appropriate* }\end{array}$ & $8 / 10$ \\
\hline $\begin{array}{l}\text { Dalemans, de } \\
\text { Witte, Beurskens } \\
\text { et al. (2010) }\end{array}$ & III & $\begin{array}{l}\text { (b) somewhat } \\
\text { representative of } \\
\text { the average in } \\
\text { the target } \\
\text { population* }\end{array}$ & $\begin{array}{l}\text { (a) justified and } \\
\text { appropriate* }\end{array}$ & $\begin{array}{l}\text { 1. (a) } \\
\text { comparability } \\
\text { between } \\
\text { respondents' and } \\
\text { non-respondents' } \\
\text { characteristics is } \\
\text { established and } \\
\text { satisfactory* } \\
\text { 2. (b) hospital } \\
\text { controls }\end{array}$ & $\begin{array}{l}\text { (a) screening tool } \\
\text { with moderate } \\
\text { validity* }\end{array}$ & $\begin{array}{l}\text { (a) controlled for } \\
\text { aphasia* } \\
\text { (b) controlled for } \\
\text { age, time post } \\
\text { stroke and } \\
\text { premorbid } \\
\text { conditions* }\end{array}$ & $\begin{array}{l}\text { 1. (c) self-report } \\
\text { 2. Yes }\end{array}$ & $\begin{array}{l}\text { (a) clearly } \\
\text { described and } \\
\text { appropriate* }\end{array}$ & $7 / 10$ \\
\hline $\begin{array}{l}\text { Darrigrand et al. } \\
\text { (2011) }\end{array}$ & III & $\begin{array}{l}\text { (c) selected } \\
\text { group of } \\
\text { participants }\end{array}$ & (b) not justified & $\begin{array}{l}\text { 1. (a) } \\
\text { comparability } \\
\text { between }\end{array}$ & $\begin{array}{l}\text { (a) validated } \\
\text { measurement } \\
\text { tool on follow }\end{array}$ & $\begin{array}{l}\text { (a) controlled for } \\
\text { aphasia* } \\
\text { (b) controlled for }\end{array}$ & $\begin{array}{l}\text { 1. (c) self-report } \\
\text { 2. Yes }\end{array}$ & $\begin{array}{l}\text { (a) clearly } \\
\text { described and } \\
\text { appropriate* }\end{array}$ & $6 / 10$ \\
\hline
\end{tabular}




\begin{tabular}{|c|c|c|c|c|c|c|c|c|c|}
\hline & & & & $\begin{array}{l}\text { respondents' and } \\
\text { non-respondents' } \\
\text { characteristics is } \\
\text { established and } \\
\text { satisfactory* } \\
\text { 2. (b) hospital } \\
\text { control }\end{array}$ & up** & age, language* & & & \\
\hline $\begin{array}{l}\text { Hilari \& } \\
\text { Northcott (2006) }\end{array}$ & III & $\begin{array}{l}\text { (b) somewhat } \\
\text { representative of } \\
\text { the average in } \\
\text { the target } \\
\text { population* }\end{array}$ & $\begin{array}{l}\text { (a) justified and } \\
\text { appropriate* }\end{array}$ & $\begin{array}{l}\text { 1. (b) } \\
\text { comparability } \\
\text { between } \\
\text { respondents and } \\
\text { non-respondents } \\
\text { is not satisfactory } \\
\text { 2. no control }\end{array}$ & $\begin{array}{l}\text { (a) screening tool } \\
\text { with moderate } \\
\text { validity* }\end{array}$ & $\begin{array}{l}\text { (a) controlled for } \\
\text { aphasia* } \\
\text { (b) controlled for } \\
\text { post-stroke time } \\
\text { period and pre- } \\
\text { morbid } \\
\text { conditions* }\end{array}$ & $\begin{array}{l}\text { 1. (c) self-report } \\
\text { 2. N/A }\end{array}$ & $\begin{array}{l}\text { (a) clearly } \\
\text { described and } \\
\text { appropriate* }\end{array}$ & $6 / 10$ \\
\hline $\begin{array}{l}\text { Matos et al. } \\
\text { (2014) }\end{array}$ & III & $\begin{array}{l}\text { (c) selected } \\
\text { group of } \\
\text { participants }\end{array}$ & (b) not justified & $\begin{array}{l}\text { 1. (a) } \\
\text { comparability } \\
\text { between } \\
\text { respondents' and } \\
\text { non-respondents' } \\
\text { characteristics is } \\
\text { established and } \\
\text { satisfactory* } \\
2 . \text { (c) No } \\
\text { description }\end{array}$ & $\begin{array}{l}\text { (a) validated } \\
\text { measurement } \\
\text { tool** }\end{array}$ & $\begin{array}{l}\text { (a) controlled for } \\
\text { aphasia* } \\
\text { (b) controlled for } \\
\text { age, language, } \\
\text { living place, } \\
\text { cognitive and } \\
\text { hearing } \\
\text { functioning* }\end{array}$ & $\begin{array}{l}\text { 1. (b) self-report } \\
\text { 2. N/A }\end{array}$ & $\begin{array}{l}\text { N/A } \\
\text { No statistical test } \\
\text { conducted. } \\
\text { Qualitative } \\
\text { analysis } \\
\text { (Thematic } \\
\text { analysis based on } \\
\text { ICF) }\end{array}$ & $5 / 10$ \\
\hline $\begin{array}{l}\text { Naess et al. } \\
\text { (2009) }\end{array}$ & III & $\begin{array}{l}\text { (c) selected } \\
\text { group of } \\
\text { participants }\end{array}$ & (b) not justified & $\begin{array}{l}\text { 1. (a) } \\
\text { comparability } \\
\text { between } \\
\text { respondents' and } \\
\text { non-respondents' } \\
\text { characteristics is } \\
\text { established and } \\
\text { satisfactory* } \\
\text { 2. (b) hospital } \\
\text { control }\end{array}$ & $\begin{array}{l}\text { (b) non-validated } \\
\text { assessment tool } \\
\text { for aphasia, but } \\
\text { the tool is } \\
\text { available* }\end{array}$ & $\begin{array}{l}\text { (a) controlled for } \\
\text { aphasia* } \\
\text { (b) controlled for } \\
\text { age* }\end{array}$ & $\begin{array}{l}\text { 1. (c) self-report } \\
\text { 2. Yes }\end{array}$ & $\begin{array}{l}\text { (a) clearly } \\
\text { described and } \\
\text { appropriate* }\end{array}$ & $5 / 10$ \\
\hline $\begin{array}{l}\text { Łapkiewicz \& } \\
\text { Grochmal-bach }\end{array}$ & III & $\begin{array}{l}\text { (c) selected } \\
\text { group of }\end{array}$ & (b) not justified & $\begin{array}{l}\text { 1. (c) no } \\
\text { description of the }\end{array}$ & $\begin{array}{l}\text { (a) validated } \\
\text { measurement }\end{array}$ & $\begin{array}{l}\text { (a) controlled for } \\
\text { aphasia* }\end{array}$ & $\begin{array}{l}\text { 1. (b) self-report } \\
\text { 2. Yes }\end{array}$ & $\begin{array}{l}\text { (a) clearly } \\
\text { described and }\end{array}$ & $4 / 10$ \\
\hline
\end{tabular}




\begin{tabular}{|c|c|c|c|c|c|c|c|c|c|}
\hline (2008) & & participants & & $\begin{array}{l}\text { response rate or } \\
\text { the } \\
\text { characteristics of } \\
\text { the responders } \\
\text { and non- } \\
\text { responders } \\
\text { 2. (b) hospital } \\
\text { control }\end{array}$ & tool** & & & appropriate* & \\
\hline Lee et al. (2015) & III & $\begin{array}{l}\text { (c) selected } \\
\text { group of } \\
\text { participants }\end{array}$ & (b) not justified & $\begin{array}{l}\text { 1. (c) no } \\
\text { description of the } \\
\text { response rate or } \\
\text { the } \\
\text { characteristics of } \\
\text { the responders } \\
\text { and non- } \\
\text { responders } \\
\text { 2. (b) hospital } \\
\text { control }\end{array}$ & $\begin{array}{l}\text { (a) screening tool } \\
\text { with moderate } \\
\text { validity* }\end{array}$ & $\begin{array}{l}\text { (a) controlled for } \\
\text { aphasia* } \\
\text { (b) controlled for } \\
\text { language, time } \\
\text { post-stroke, pre- } \\
\text { morbid } \\
\text { conditions, } \\
\text { functioning at } \\
\text { assessment* }\end{array}$ & $\begin{array}{l}\text { 1. (c) self-report } \\
\text { 2. Yes }\end{array}$ & $\begin{array}{l}\text { (a) clearly } \\
\text { described and } \\
\text { appropriate* }\end{array}$ & $4 / 10$ \\
\hline $\begin{array}{l}\text { Dalemans, de } \\
\text { Witte, Wade et al. } \\
\text { (2010) }\end{array}$ & III & $\begin{array}{l}\text { (c) selected } \\
\text { group of } \\
\text { participants }\end{array}$ & (b) not justified & $\begin{array}{l}\text { 1. (b) } \\
\text { comparability } \\
\text { between } \\
\text { respondents and } \\
\text { non-respondents } \\
\text { not satisfactory } \\
\text { 2. (c) no control }\end{array}$ & $\begin{array}{l}\text { (a) screening tool } \\
\text { with moderate } \\
\text { validity* }\end{array}$ & $\begin{array}{l}\text { (a) controlled for } \\
\text { aphasia* } \\
\text { (b) controlled for } \\
\text { time post-stroke, } \\
\text { age, living place, } \\
\text { caregiver* }\end{array}$ & $\begin{array}{l}\text { 1. (c) self-report } \\
\text { 2. N/A }\end{array}$ & $\begin{array}{l}\text { N/A } \\
\text { No statistical } \\
\text { analysis. } \\
\text { Qualitative } \\
\text { analysis with use } \\
\text { of an online } \\
\text { software } \\
\text { program. } \\
\text { Description fair. }\end{array}$ & $3 / 10$ \\
\hline $\begin{array}{l}\text { Fotiadou et al. } \\
\text { (2014) }\end{array}$ & III & $\begin{array}{l}\text { (c) selected } \\
\text { group of } \\
\text { participants }\end{array}$ & (b) not justified & $\begin{array}{l}\text { 1. (a) } \\
\text { comparability } \\
\text { between } \\
\text { respondents' and } \\
\text { non-respondents' } \\
\text { characteristics is } \\
\text { established and } \\
\text { satisfactory* } \\
\text { 2. (c) no control }\end{array}$ & $\begin{array}{l}\text { (c) no description } \\
\text { of a } \\
\text { measurement } \\
\text { tool }\end{array}$ & $\begin{array}{l}\text { (a) controlled for } \\
\text { aphasia* } \\
\text { (b) controlled for } \\
\text { language, age, } \\
\text { content* }\end{array}$ & $\begin{array}{l}\text { 1. (c) self-report } \\
\text { 2. N/A }\end{array}$ & $\begin{array}{l}\text { N/A } \\
\text { No statistical } \\
\text { analysis. } \\
\text { Framework } \\
\text { analysis } \\
\text { completed. } \\
\text { Method of } \\
\text { analysis } \\
\text { qualitative and }\end{array}$ & $3 / 10$ \\
\hline
\end{tabular}




\begin{tabular}{|c|c|c|c|c|c|c|c|c|c|}
\hline & & & & & & & & well described & \\
\hline $\begin{array}{l}\text { Pommerehn et al. } \\
\text { (2016) }\end{array}$ & III & $\begin{array}{l}\text { (c) selected } \\
\text { group of } \\
\text { participants }\end{array}$ & (b) not justified & $\begin{array}{l}\text { 1. (c) no } \\
\text { description of the } \\
\text { response rate or } \\
\text { the } \\
\text { characteristics of } \\
\text { the responders } \\
\text { and non- } \\
\text { responders } \\
\text { 2. (c) no control }\end{array}$ & $\begin{array}{l}\text { (c) no description } \\
\text { of the } \\
\text { measurement } \\
\text { tool }\end{array}$ & $\begin{array}{l}\text { (a) controlled for } \\
\text { aphasia* } \\
\text { (b) controlled for } \\
\text { age, participation } \\
\text { in therapy* }\end{array}$ & $\begin{array}{l}\text { 1. (c) self-report } \\
\text { 2. N/A }\end{array}$ & $\begin{array}{l}\text { N/A } \\
\text { No statistical } \\
\text { analysis. } \\
\text { Thematic } \\
\text { analysis based on } \\
\text { ICF. }\end{array}$ & $2 / 10$ \\
\hline
\end{tabular}


Table 3. Domestic life

\begin{tabular}{|c|c|c|c|c|}
\hline Author & Measurements instruments & $\begin{array}{l}\text { Mean months } \\
\text { post onset } \\
\text { (R/SD) }\end{array}$ & Concepts & Results \\
\hline $\begin{array}{l}\text { Mazaux et al. } \\
\text { (2013) }\end{array}$ & $\begin{array}{l}\text { Orgogozo's score, Barthel } \\
\text { Index, ASRS, BDAE (French } \\
\text { version), TLC, ECVB }\end{array}$ & (R 12-18) & domestic activities & $\begin{array}{l}\text { Most impaired activities: conversation on complex themes, using the phone } \\
\text { for a meeting, using checks and credit cards, communicating during social } \\
\text { activities. Least impaired: asking for daily living needs, talking about one's } \\
\text { wishes and purposes, expressing feelings, conversation with relatives, } \\
\text { answering on a phone, reading time and reading family post/mail. ECVB } \\
\text { scores associated with work status and type of job at inclusion, stroke } \\
\text { severity at inclusion and follow-up, aphasia severity at inclusion and } \\
\text { follow-up, auditory comprehension impairment on inclusion, BDAE items } \\
\text { of auditory comprehension, fluency, naming, reading and writing at } \\
\text { follow-up, mean number of SLT sessions, depression at follow-up. }\end{array}$ \\
\hline $\begin{array}{l}\text { Dalemans, De } \\
\text { Witte, } \\
\text { Beurskens et al. } \\
(2010)\end{array}$ & $\begin{array}{l}\text { Structured interview, } \\
\text { FAST, Barthel Index, COOP- } \\
\text { WONCA, Personal Factors } \\
\text { Questionnaire, Environmental } \\
\text { Factors Questionnaire, CIQ }\end{array}$ & $\begin{array}{l}90.6 \\
(\mathrm{R} 6-372)\end{array}$ & home integration & $\begin{array}{l}\text { Home integration score of } 4.8 \text { (max score: } 12 \text { ) on CIQ subscale (SD: } 3.6 \\
\text { Range: } 0-12 \text { ). }\end{array}$ \\
\hline $\begin{array}{l}\text { Matos et al. } \\
\text { (2014) }\end{array}$ & $\begin{array}{l}\text { In-depth semi-structured } \\
\text { interview }\end{array}$ & $\begin{array}{l}29 \\
\text { (R 3-89) }\end{array}$ & domestic activities & $\begin{array}{l}\text { PWA reported difficulties participating in household tasks, but this was not } \\
\text { identified as the domain most impacted by the aphasia. }\end{array}$ \\
\hline Lee et al. (2015) & Modified Barthel Index; FAST; & 29.1 & home integration & Home integration scores: PWA- Mean: 2.6, SD: 3.0, Control- Mean: 5.6, \\
\hline
\end{tabular}




\begin{tabular}{|l|l|l|l|l|}
\hline & GDS; CIQ; SAQOL-39 & (SD 20.6) & $\begin{array}{l}\text { SD: 3.0. PWA spent less time on activities of market, finance, shopping. } \\
\text { No significant difference observed in meal preparation and household } \\
\text { activities. Factors impacting on home integration: activities of daily living } \\
\text { and mobility. }\end{array}$ \\
\hline $\begin{array}{l}\text { Pommerehn et } \\
\text { al. (2016) }\end{array}$ & ICF checklist & $\begin{array}{l}52 \\
\text { (R 26.4-136.8) }\end{array}$ & $\begin{array}{l}\text { household chores, } \\
\text { acquisition of goods } \\
\text { and services, meal } \\
\text { preparation, helping } \\
\text { others }\end{array}$ & $\begin{array}{l}\text { Predominant difficulties with meal preparation, household chores, goods } \\
\text { and services acquisition and helping others. }\end{array}$ \\
\hline
\end{tabular}

Abbreviations: ASRS: Goodglass and Kaplan Aphasia Severity Rating Scale, Barthel Index: Barthel Activities of Daily Living Index, BDAE: Boston Diagnostic Aphasia Examination, CIQ: Community Integration Questionnaire, COOP-WONCA: Darmouth Coop Functional Health Assessment Charts/Wonca, ECVB: Echelle de Communication Verbale de Bordeaux, GDS: Geriatric Depression Scale, FAST: Frenchay Aphasia Screening Test, R: Range, SAQOL-39: Stroke and Aphasia Quality of Life Scale-39, SD: Standard deviation, TLC: Test Lillois de Communication 
Table 4. Interpersonal relations and interactions

\begin{tabular}{|c|c|c|c|c|}
\hline Author & Measurements instruments & $\begin{array}{l}\text { Mean months } \\
\text { post onset } \\
(\mathrm{R} / \mathrm{SD})\end{array}$ & Concepts & Results \\
\hline $\begin{array}{l}\text { Hilari \& } \\
\text { Northcott (2006) }\end{array}$ & $\begin{array}{l}\text { SAQOL-39, MOS-SSS, a social } \\
\text { network questionnaire }\end{array}$ & $\begin{array}{l}42 \\
(\mathrm{R} 13-250)\end{array}$ & $\begin{array}{l}\text { social networks, } \\
\text { perceived social } \\
\text { support, HRQL }\end{array}$ & $\begin{array}{l}86.3 \% \text { of PWA reported maintained or increased contact with their } \\
\text { children, and } 75.4 \% \text { with their relatives, while } 63.9 \% \text { reported less } \\
\text { contact with friends, with } 30 \% \text { being unable to name a single close friend. } \\
\text { Decreased social network size (Mean: } 10 \text {; Mode } 4 \text { ), with the general } \\
\text { population having between } 8-15 \text { members in their social network. Size of } \\
\text { social network in women, social companionship and informational } \\
\text { support associated with HRQL. Overall PWA felt well supported, } \\
\text { particularly in tangible support. }\end{array}$ \\
\hline $\begin{array}{l}\text { Matos et al. } \\
(2014)\end{array}$ & $\begin{array}{l}\text { In-depth semi-structured } \\
\text { interview } \\
\text { Analyses according to ICF } \\
\text { framework }\end{array}$ & $\begin{array}{l}29 \\
\text { (R 3-89) }\end{array}$ & $\begin{array}{l}\text { interpersonal } \\
\text { relationships }\end{array}$ & $\begin{array}{l}\text { PWA reported significant changes in their relationships, and noted } \\
\text { changes or loss of friendships. }\end{array}$ \\
\hline $\begin{array}{l}\text { Naess et al. } \\
(2009)\end{array}$ & $\begin{array}{l}\text { MASRS, Nottingham Health } \\
\text { Profile questionnaire part I, } \\
\text { SSS, NGA, CETI }\end{array}$ & $\geq 60$ & social isolation & Aphasia is associated with social isolation ( $\mathrm{p}=0.054$; Fisher exact). \\
\hline $\begin{array}{l}\text { Lapkiewicz \& } \\
\text { Grochmal-bach } \\
(2008)\end{array}$ & $\begin{array}{l}\text { MMSE, GDS, CNBA, BNT } \\
\text { (Polish version), TT, DAS, } \\
\text { MCQ }\end{array}$ & 6 & $\begin{array}{l}\text { marital coherence, } \\
\text { perceived support, } \\
\text { QOL }\end{array}$ & $\begin{array}{l}\text { PWA found a loss of harmony, satisfaction, cohesion, emotional } \\
\text { expression, faith in the value of marriage. PWA showed more extensive } \\
\text { changes in the marriage as well as in more significant areas of marriage as } \\
\text { compared to individuals with stroke and no aphasia. }\end{array}$ \\
\hline $\begin{array}{l}\text { Fotiadou et al. } \\
(2014)\end{array}$ & $\begin{array}{l}\text { Thematic analysis of blog } \\
\text { content using Framework } \\
\text { Analysis }\end{array}$ & $\geq 12$ & $\begin{array}{l}\text { social networks, social } \\
\text { support, family } \\
\text { dynamics; factors } \\
\text { impacting on social } \\
\text { relationships }\end{array}$ & $\begin{array}{l}\text { In-depth conversations more challenging, reduced participation in family } \\
\text { activities, higher degrees of dependence and changed family dynamics } \\
\text { and roles. Contact with friends was reduced (communication and physical } \\
\text { difficulties impacting). Wider social networks mostly reduced (related to } \\
\text { reduced work and community activities as well as environmental barriers } \\
\text { and fatigue). Other people's reactions as well as support towards the } \\
\text { PWA had a big impact on the individual. }\end{array}$ \\
\hline Pommerehn et al. & ICF checklist & 52 & relationships & Predominant difficulties with informal and formal relations with family \\
\hline
\end{tabular}




\begin{tabular}{|l|l|l|l|}
\hline (2016) & (R 26.4-136.8) & and strangers. \\
\hline Abbreviations: Barthel Index: Barthel Activities of Daily Living Index, BNT: Boston Naming Test, CETI: Communic
\end{tabular}

Abbreviations: Barthel Index: Barthel Activities of Daily Living Index, BNT: Boston Naming Test, CETI: Communication Effectiveness Index, CIQ: Community Integration

Questionnaire, CNBA: Cracow Neurpsychological Battery for Aphasia Examinations, COOP-WONCA: Darmouth Coop Functional Health Assessment Charts/Wonca, DAS:

Dyadic Adjustment Scale, FAST: Frenchay Aphasia Screening Test, GDS: Geriatric Depression Scale, HRQL: Health Related Quality of Life, MASRS; Montgomery-

Asberg Depression Rating Scale, MCQ: Marital Communication Questionnaire, MMSE: Mini-Mental-State Examination, MOS-SSS: Medical Outcome Study Social Support

Survey, NGA: Norsk Grunntest for Afasi, QOL: Quality of Life, R: Range, SAQOL-39: Stroke and Aphasia Quality of Life Scale-39, SD: Standard deviation, SSS:

Scandinavian Stroke Scale, TT: Token Test 
Table 5. Education and employment

\begin{tabular}{|c|c|c|c|c|}
\hline Author & Measurements instruments & $\begin{array}{l}\text { Mean months } \\
\text { post onset } \\
(\mathrm{R} / \mathrm{SD})\end{array}$ & Concepts & Results \\
\hline $\begin{array}{l}\text { Dalemans, de } \\
\text { Witte, Beurskens } \\
\text { et al. (2010) }\end{array}$ & $\begin{array}{l}\text { Structured interview, } \\
\text { FAST, Barthel Index, COOP- } \\
\text { WONCA, Personal Factors } \\
\text { Questionnaire, Environmental } \\
\text { Factors Questionnaire, CIQ }\end{array}$ & $\begin{array}{l}90.6 \\
(\mathrm{R} 6-372)\end{array}$ & productivity & $\begin{array}{l}\text { Mean productivity score on subscale of CIQ (SD: 1.6, Range: 0-5) (max } \\
\text { score=5). }\end{array}$ \\
\hline $\begin{array}{l}\text { Hilari \& } \\
\text { Northcott (2006) }\end{array}$ & $\begin{array}{l}\text { SAQOL-39, MOS-SSS, a social } \\
\text { network questionnaire }\end{array}$ & $\begin{array}{l}42 \\
(\mathrm{R} 13-250)\end{array}$ & return to work & $\begin{array}{l}\text { No PWA returned to full-time employment. Only } 6 \% \text { of PWA were } \\
\text { involved in part-time or voluntary work/students, and } 56 \% \text { were of } \\
\text { working age. }\end{array}$ \\
\hline $\begin{array}{l}\text { Matos et al. } \\
(2014)\end{array}$ & Semi-structured interview & $\begin{array}{l}29 \\
(\mathrm{R} 3-89)\end{array}$ & employment & $\begin{array}{l}\text { PWA reported loss of employment and changes in their ability to } \\
\text { participate at work. }\end{array}$ \\
\hline $\begin{array}{l}\text { Naess et al. } \\
(2009)\end{array}$ & $\begin{array}{l}\text { MASRS, Nottingham Health } \\
\text { Profile questionnaire part I, } \\
\text { SSS, NGA, CETI }\end{array}$ & $\geq 60$ & return to work & $\begin{array}{l}\text { Of ischemic stroke patients employed before the incident, } 33 \% \text { of PWA } \\
\text { and } 69 \% \text { of those without aphasia were employed on follow-up. }\end{array}$ \\
\hline Lee et al. (2015) & $\begin{array}{l}\text { Modified Barthel Index; FAST; } \\
\text { GDS; CIQ; SAQOL-39 }\end{array}$ & $\begin{array}{l}29.1 \\
(\mathrm{SD} 20.6)\end{array}$ & productivity & $\begin{array}{l}\text { Productivity scores: PWA (Mean: 0.3; SD: 0.8), Control (Mean: 2.8, SD: } \\
\text { 1.8). PWA spent less time on education than the control group. }\end{array}$ \\
\hline $\begin{array}{l}\text { Fotiadou et al. } \\
(2014)\end{array}$ & $\begin{array}{l}\text { Thematic analysis of blog } \\
\text { content using Framework } \\
\text { Analysis }\end{array}$ & $\geq 12$ & $\begin{array}{l}\text { return to work, factors } \\
\text { impacting return to } \\
\text { work }\end{array}$ & $\begin{array}{l}\text { 2/10 individuals were employed post-stroke. Factors impacting return to } \\
\text { work: aphasia, fatigue, older age, epilepsy, short attention span and } \\
\text { difficulty multitasking. }\end{array}$ \\
\hline $\begin{array}{l}\text { Pommerehn et al. } \\
\text { (2016) }\end{array}$ & ICF checklist & $\begin{array}{l}52 \\
(\mathrm{R} 26.4-136.8)\end{array}$ & employment & $\begin{array}{l}\text { Predominant difficulties with basic economic transactions and performing } \\
\text { paid work. }\end{array}$ \\
\hline
\end{tabular}

Abbreviations: Barthel Index: Barthel Activities of Daily Living Index, CETI: Communication Effectiveness Index, CIQ: Community Integration Questionnaire, COOP-

WONCA: Darmouth Coop Functional Health Assessment Charts/Wonca, FAST: Frenchay Aphasia Screening Test, GDS: Geriatric Depression Scale, MASRS; Montgomery-

Asberg Depression Rating Scale, MOS-SSS: Medical Outcome Study Social Support Survey, NGA: Norsk Grunntest for Afasi, R: Range, SAQOL-39: Stroke and Aphasia

Quality of Life Scale-39, SD: Standard deviation, SSS: Scandinavian Stroke Scale 
Table 6. Community, civic and social life

\begin{tabular}{|c|c|c|c|c|}
\hline Author & Measurements instruments & $\begin{array}{l}\text { Mean months } \\
\text { post onset } \\
\text { (R/SD) }\end{array}$ & Concepts & Results \\
\hline $\begin{array}{l}\text { Dalemans, de } \\
\text { Witte, Beurskens, } \\
\text { et al. (2010) }\end{array}$ & $\begin{array}{l}\text { Structured interview, } \\
\text { FAST, Barthel Index, COOP- } \\
\text { WONCA, Personal Factors } \\
\text { Questionnaire, Environmental } \\
\text { Factors Questionnaire, CIQ }\end{array}$ & $\begin{array}{l}90.6 \\
(\mathrm{R} 6-372)\end{array}$ & social integration & $\begin{array}{l}\text { Mean social integration score of } 8.4(\mathrm{SD}=2.2 \text {, range: } 2-12) \text { (max score: } \\
\text { 20). }\end{array}$ \\
\hline $\begin{array}{l}\text { Matos et al. } \\
(2014)\end{array}$ & Semi-structured interview & $\begin{array}{l}29 \\
\text { (R 3-89) }\end{array}$ & recreation and leisure & $\begin{array}{l}\text { PWA reported particular restrictions in participating in recreation and } \\
\text { leisure activities. }\end{array}$ \\
\hline $\begin{array}{l}\text { Pommerehn et al. } \\
\text { (2016) }\end{array}$ & ICF checklist & $\begin{array}{l}52 \\
\text { (R 26.4-136.8) }\end{array}$ & $\begin{array}{l}\text { community life, } \\
\text { recreation and leisure, } \\
\text { religion and } \\
\text { spirituality, political } \\
\text { life and citizenship }\end{array}$ & $\begin{array}{l}\text { Participants noted the greatest disability in community life, followed by } \\
\text { recreation and leisure and political life and citizenship. }\end{array}$ \\
\hline
\end{tabular}

Abbreviations: Barthel Index: Barthel Activities of Daily Living Index, CIQ: Community Integration Questionnaire, FAST: Frenchay Aphasia Screening Test, GDS: Geriatric

Depression Scale, R: Range, SAQOL-39: Stroke and Aphasia Quality of Life Scale-39, SD: Standard deviation 
Table 7. Contextual factors impacting on social participation

\begin{tabular}{|c|c|c|c|c|}
\hline Author & Measurements instruments & $\begin{array}{l}\text { Mean months } \\
\text { post onset } \\
(\mathrm{R} / \mathrm{SD})\end{array}$ & Concepts & Results \\
\hline $\begin{array}{l}\text { Dalemans, Witte, } \\
\text { Beurskens, et al. } \\
(2010)\end{array}$ & $\begin{array}{l}\text { Structured interview, } \\
\text { FAST, Barthel Index, COOP- } \\
\text { WONCA, Personal Factors } \\
\text { Questionnaire, Environmental } \\
\text { Factors Questionnaire, CIQ }\end{array}$ & $\begin{array}{l}90.6 \\
(\mathrm{R} \mathrm{6-372)}\end{array}$ & $\begin{array}{l}\text { personal factors, } \\
\text { environmental factors }\end{array}$ & $\begin{array}{l}\text { Factors impacting social participation: age, gender, performance on } \\
\text { fADLs and aphasia severity }(\beta=0.205) \text {. Environmental and personal } \\
\text { factors do not independently impact on social participation. }\end{array}$ \\
\hline $\begin{array}{l}\text { Dalemans, de } \\
\text { Witte, Wade, et } \\
\text { al. (2010) }\end{array}$ & $\begin{array}{l}\text { FAST } \\
\text { Pre-structured diary } \\
\text { Semi-structured interview } \\
\text { Focus group interview }\end{array}$ & $\begin{array}{l}61.5 \\
(\mathrm{R} 16-132)\end{array}$ & $\begin{array}{l}\text { engagement, personal } \\
\text { factors, social factors, } \\
\text { environmental factors, }\end{array}$ & $\begin{array}{l}\text { The level of engagement in social activities is more important than the } \\
\text { number of activities. Personal factors: motivation, physical and } \\
\text { psychological condition, communication skills; Social factors: the role of } \\
\text { the central caregiver, characteristics of the communication partners } \\
\text { (willingness, skills and knowledge); Environmental factors: quietness and } \\
\text { familiarity of living place. }\end{array}$ \\
\hline $\begin{array}{l}\text { Pommerehn et al. } \\
\text { (2016) }\end{array}$ & ICF checklist & $\begin{array}{l}52 \\
\text { (R 26.4-136.8) }\end{array}$ & contextual factors & $\begin{array}{l}\text { Most reported the following factors as facilitators of social participation: } \\
\text { attitude, physical, practical or emotional support from people PWA lives } \\
\text { with, however certain individuals noted these same factors as barriers to } \\
\text { participation. Additional barriers identified: services, training policies, } \\
\text { work and employment. }\end{array}$ \\
\hline
\end{tabular}

Abbreviations: Barthel Index: Barthel Activities of Daily Living Index, CIQ: Community Integration Questionnaire, COOP-WONCA: Darmouth Coop Functional Health Assessment Charts/Wonca, FAST: Frenchay Aphasia Screening Test R: Range, SD: Standard deviation 


\section{List of figures}

Figure 1. PRISMA flow chart of selection process 
PubMed, Scopus, PsychINFO

2005-2017, English, Original studies only

2,864 Citation(s)

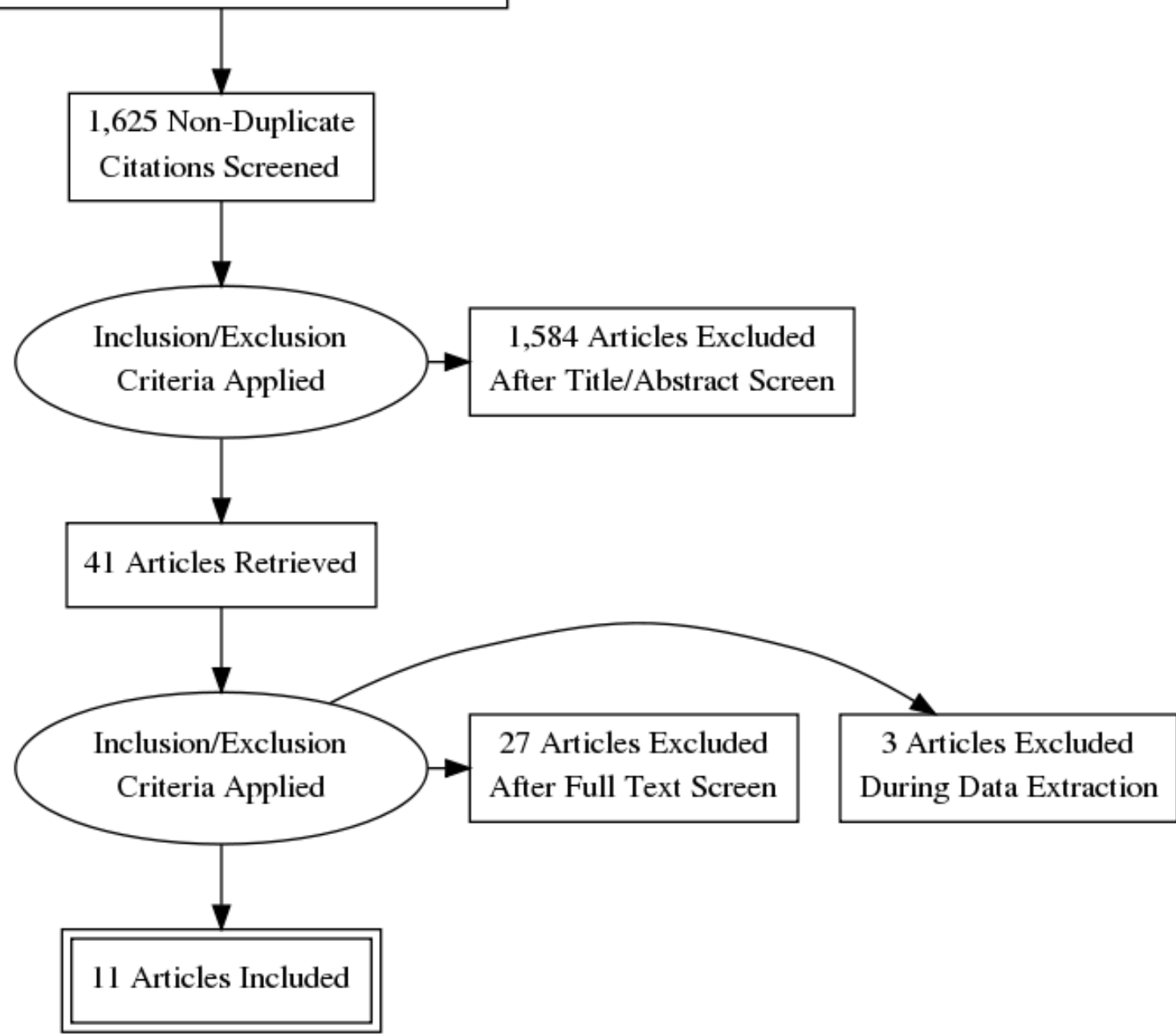

Figure 1. PRISMA flow chart of selection process 


\section{CHAPTER 4}

\section{Aim of the chapter:}

The aim of this chapter is to discuss the implications of the research findings, to describe limitations in the study, to identify future avenues of study and to draw a final conclusion.

\subsection{Implications of the research findings}

The use of social models, as opposed to medical models, for assessment and intervention is gaining momentum across many medical fields. A more holistic approach to managing clients is being embraced in order to encourage optimal recovery, participation and ultimately an improved QOL. In line with this change in approach, this systematic review was conducted to determine to what extent aphasia impacts on the social participation of working-age adults. Eleven studies meeting the criteria for this review on social participation were included and all were identified to be on a Level III ASHA evidence level, with variation on the NOS rating scale from a low score of 2/10 to a high score of $8 / 10$, with six of the eleven studies obtaining more than 5/10. Four of the eleven studies used the ICF, or components thereof, to guide or structure the study or data interpretation (Darrigrand et al., 2011; Matos et al., 2014; Mazaux et al., 2013; Pommerehn et al., 2016), while no studies used the A-FROM. Dalemans et al. (2008) reported that only seven of the 18 studies included in their review were published after the development of the ICF, which limited the use of the framework, however all studies in the current review were published after this time. It appears that there continues to be limitations in knowledge regarding the social participation of this population of individuals. Overall, it is evident that social participation across the four domains is greatly reduced for working-age PWA.

Six studies investigating domestic life are in agreement that domestic life for young individuals is negatively impacted by aphasia in a variety of ways. Many of the factors investigated are required on a daily basis, including using a phone, filling in forms, shopping and communicating in social settings. Dalemans et al. (2008) also concluded that there is a decrease in domestic activities in this population. This 
highlights the need to address functional communication skills in speech-language therapy intervention and to include the patient and family in goal setting. The PWA may identify simple daily skills that they wish to achieve and that may be targeted in treatment. As previously mentioned, research indicates that both PWA and their family members identify increased life participation as key areas in which they would like to improve (Isaksen, 2014). One cannot ignore the need to educate the client, families and public on the presenting condition in order to minimise limitations to participating in domestic life and to reduce barriers in the environment. Restrictions in resources of low income countries, such as South Africa, prove a greater challenge in facilitating this aspect.

Interpersonal relations and interactions in PWA are reduced, with a decline in the size of social networks, loss of friendships and changes in the quality of marital relations. This decline in social contacts was also found by Dalemans et al. (2008) in working-age PWA, however they also noted changes in the quality of interactions across friendships and family relationships, and not just marital relationships as the current study identified. Dalemans et al. (2008) found a decrease in sexual activity, an aspect that was not identified in the current review. This knowledge regarding the changes in interpersonal relations and interaction in PWA should lead one to focus on education of the public and family on aphasia and strategies to improve communication. This concept is frequently emphasised, but not always practiced (Roth \& Worthington, 2005). Communication is the basis of relationships. In PWA, communication is altered, and without knowledge of how to facilitate communication, friends and family may easily become overwhelmed and avoid the challenging situations. Sufficient knowledge and skills will facilitate communication and therefore relationships with various people in the PWA's life. Increased informational support and social companionships is associated with greater HRQL (Hilari \& Northcott, 2006) and meaningful relationships to 'living successfully with aphasia' (Brown et al., 2012).

A number of studies investigated education and employment. Few PWA return to work and many report changes in their ability to participate in work tasks as well as productive activity, which are similar findings to what Dalemans et al. (2008) found. While Dalemans et al. (2008) did not find research regarding the changes in education in PWA, the current review found that PWA spend less time on education 
than individuals without stroke and some PWA feel moderate to severe limitations in their ability to participate in educational-type activities, including informal education. These findings not only emphasise the need to address skills required for work or some form of productive activity in therapy, but also the need to educate society and make changes in the environment (Graham et al., 2011). The current review was investigating working-age adults. These individuals would most likely be employed or engaged in some form of productive activity, if they did not have aphasia, and yet there are severe limitations. Many of these individuals were the primary breadwinner in the family, and they may still be required to assist financially. Barriers in the work-place in addition to the individual's symptoms of aphasia limit their ability to return to work or education. As indicated on the ICF, contextual factors have a great influence on participation (WHO, 2001). If one could reduce the contextual barriers, however, participation would be facilitated, and this concept is strongly emphasised by proponents of the social model of disability (Hallowell, 2017).

The domain with the most limited research in both the current review and Dalemans et al. (2008) was that of community, civic and social life. The studies indicated limitations in social integration, including aspects such as going-out and leisure activities, which is in accordance with the findings of Dalemans et al. (2008). While Dalemans et al. (2008) only found studies that commented on leisure activities, the current review found a slight increase in research in this domain. It appears that PWA found greatest limitations in community life, followed by recreation and leisure and political life and citizenship. Few individuals found limitations in religion and spirituality. While conclusions must be drawn cautiously due to the limited data, it appears that community, civic and social life is negatively affected in working-age PWA. This has implications for QOL and Cruice, Worrall, and Hickson (2006) recommend encouraging leisure activities in PWA. The same can be highlighted for the remaining aspects of community, civic and social life.

An area of more recent research is the impact of contextual factors on social participation on PWA. This was highlighted as an area for further research by Dalemans et al. (2008) as the researchers were unable to find studies investigating this topic. While one study did not find that environmental and personal factors impact on social participation, the remaining two studies did, with a key environmental factor facilitating participation being the support of the central 
caregiver of the individuals with whom the PWA spends the most time. While research is limited, it is evident that one cannot ignore the barrier- or facilitatingeffect contextual factors may have on the PWA (WHO, 2001). As discussed, the attention to contextual factors becomes particularly relevant in low income countries, where resources that may facilitate participation and integration are limited.

Research into social participation in PWA in this context is important to determine the extent reduced resources may have on participation. The current review did not identify any studies conducted in Africa or South Africa on social participation in this population, which is of concern as the incidence of stroke in the young continues to rise in this context (Maredza et al., 2015).

The current review is in agreement with many of the findings reported in Dalemans et al. (2008). Of interest is the attention given to aspects identified as limitations or areas for further research in the Dalemans et al. (2008) review. The researchers of the previous review indicated the need for the increased use of a conceptual framework to aid defining of participation. While only four studies in the current review made use of the ICF, there appears to be a greater number of studies that made use of concepts of the ICF, which may enable more comparable results. The use of the IC is still relatively limited, however, and the A-FROM framework was not found to be used in any of the identified studies. Dalemans et al. (2008) also identified the need for research into the environmental factors impacting on social participation, and although limited, there is an expanding area of research into this aspect. Furthermore, two studies included comparisons of social participation in stroke PWA, as opposed to stroke particpants without aphasia, which was identified as an area for further research (Dalemans et al., 2008). While a number of selfdeveloped questionnaires were used in the studies included in this review, there appears to be an increased trend towards using more standardised assessment measures. An additional encouraging factor is the apparent larger sample sizes in the included studies, which contributes to the accuracy of the findings. It appears that this rising population of working-age individuals with aphasia is receiving greater attention.

It was noted in the current review, however, that the A-FROM, which is the conceptual framework developed by speech-language therapists specifically for aphasia in line with the ICF, does not currently appear to be used in research 
regarding social participation of working-age PWA. As this framework was developed in 2008, increased frequency of use would be expected, particularly as the framework specifically focuses on communication as a construct of social participation (Kagan et al., 2008). It may be that an increase in the use of frameworks for research and treatment would be facilitated with the A-FROM, as it is more tailored for aphasia than the ICF, which may previously have limited its use in previous research.

Overall, it appears that unanswered questions regarding participation in working-age adults are being investigated and new questions have arisen from the current updated review.

\subsection{Limitations in the study}

- Lack of consistency in the use of concepts:

While the use of a conceptual framework, namely the ICF, appears to be more evident, the use continues to be fairly limited and there are a number of studies in which the concept of participation, or the domains within participation, is not well defined. The use of the ICF serves to provide a clearer definition of concepts and therefore enables improved comparison between studies. A wide variety of assessment tools and questionnaires were used, which also contributes to variances in concepts used. These variations limit the ability to identify clear concepts in a number of studies and therefore to draw accurate conclusions.

- Few studies with populations limited solely to participants under the age of 65 years:

Only one study investigated participants under the age of 65 only, and only one study investigating individuals under the age of 68 only. The remaining studies all included a wide range of ages. While a limit of a mean age of 65 was set for the current study, and the younger population is highlighted with the use of this criterion, it was not possible to set a clear distinction between the young and old population of PWA at this stage.

- Studies included: 
While every effort has been made to identify all studies related to social participation, limitations in search terms and the databases selected may have resulted in pertinent studies not being included.

\subsection{Future research}

Progress has been made in the understanding of social participation in working-age adults with aphasia over the last decade, however further research into this topic is recommended.

- Further research into the working-age population specifically, is warranted, with possible investigation into the unique differences in social participation as opposed to older PWA.

- Further research is warranted to allow a more in-depth and comprehensive understanding of social participation within the context of a standardised framework. To date, the ICF has been used, however, the A-FROM may facilitate this due to the adaptation of the framework from the ICF that makes it more appropriate for research in social participation in aphasia. This may encourage researchers to make use of a framework, as it may be more applicable than the ICF.

- From the current review, it appears that more attention has been given to the social participation domains of domestic life, interpersonal relations and employment in working-age adults than to education and community, civic and social life. These less investigated social domains are aspects that are important for the young population in ways that may no longer be required for older adults. A thorough understanding of the impact aphasia has on these domains in young adults will facilitate appropriate treatment thereof.

- Although there is emerging research into the impact of contextual factors on social participation, this is fairly limited and somewhat contradictory. Further research is required to identify the overall impact of these factors, as well as the specific factors that may impact on the PWA performance and progress.

- While a few studies exist that compare the social participation of young adult with aphasia to young adults with stroke, and no aphasia, this avenue of research is fairly limited. In order to understand the true impact of aphasia, one must compare PWA to those with stroke, but no aphasia. 
- It would be useful to research how social participation may be influenced by the presenting sub-type of aphasia. There is a great difference between the presenting symptoms of fluent vs. no-fluent aphasias and these differences may be reflected in differences in social participation as well.

- A number of studies investigated the impact of different treatment approaches on social participation. It would be valuable to identify exactly which protocols have shown success in the aphasia population in order to facilitate participation.

- It is clear from this review that the research regarding social participation of young PWA is conducted primarily in middle to high income countries as compared to low income countries. Social participation and community reintegration is affected by personal, functional and environmental factors, which may be facilitated by resources that may be more readily available in middle to high income countries (Akosile et al., 2016). Due to the unique challenges in low and middle income countries, such as South Africa, further research is needed in these settings. A longitudinal study may be warranted due to the comparatively low incidence of stroke in the younger population as opposed to individuals over 65 years of age, as well as due to the challenges that a multi-lingual country poses to assessment and comparison of participants.

\subsection{Conclusion}

Working-age PWA experience limitations across the social participation domains, including domestic life, interpersonal relations and interactions, education and employment as well as community, civic and social life. There is contradictory information regarding the impact of environmental and personal factors on social participation in PWA, although a number of factors do appear to have been identified. The ICF appears to be used more frequently to guide research studies in social participation, but it is still fairly limited and there is still a lack of consistency in the use of concepts, and to a certain extent, use of standardised assessment measures, in a number of studies. These factors raise concerns which lead one to interpret the findings with some degree of caution. 


\section{REFERENCES}

Akosile, C., Nworah, C., Okoye, E., Adegoke, B., Umunnah, J., \& Fabunmi, A. (2016). Community reintegration and related factors in a Nigerian stroke sample. African Health Sciences, 16(3), 772-780. http://doi.org/10.4314/ahs.v16i3.18

Ali, M., Lyden, P., \& Brady, M. (2015). Aphasia and dysarthria in acute stroke: recovery and functional outcome. International Journal of Stroke, 10(3), 400406. http://doi.org/10.1111/ijs. 12067

American Speech-Language-Hearing Association [ASHA]. (2004). Evidence-based practice in communication disorders: an introduction. Rockville.

Andersen, K. K., Olsen, T. S., Dehlendorff, C., \& Kammersgaard, L. P. (2009). Hemorrhagic and ischemic strokes compared: stroke severity, mortality, and risk factors. Stroke, 40(6), 2068-2072.

http://doi.org/10.1161/STROKEAHA.108.540112

Bohra, V., Khwaja, G., Jain, S., Duggal, A., Ghuge, V., \& Srivastava, A. (2015). Clinicoanatomical correlation in stroke related aphasia. Annals of Indian Academy of Neurology, 180(0), 424-429. http://doi.org/10.4103/09722327.165469

Brown, K., Worrall, L. E., Davidson, B., \& Howe, T. (2012). Living successfully with aphasia: a qualitative meta-analysis of the perspectives of individuals with aphasia, family members, and speech-language pathologists. International Journal of Speech-Language Pathology, 14(2), 141-155. http://doi.org/10.3109/17549507.2011.632026

Byng, S., \& Duchan, J. (2005). Social model philosophies and principles: their applications in therapies for aphasia. Aphasiology, 19, 906-922.

Chapey, R. (2008). Language intervention strategies in aphasia and related neurogenic communication disorders (5th ed.). Philadelphia: Lippincott Williams and Wilkins.

Croquelois, A., \& Bogousslavsky, J. (2011). Stroke aphasia: 1,500 consecutive cases. Cerebrovascular Diseases, 31(4), 392-399. 
http://doi.org/10.1159/000323217

Cruice, M., Worrall, L., \& Hickson, L. (2006). Quantifying aphasic people's social lives in the context of non-aphasic peers. Aphasiology, 20(12), 1210-1225. http://doi.org/10.1080/02687030600790136

Dalemans, R. J., De Witte, L. P., Beurskens, A. J., Van den Heuvel, W. J., \& Wade, D. T. (2010). Psychometric Properties of the Community Integration Questionnaire Adjusted for People With Aphasia. Archives of Physical Medicine and Rehabilitation, 91(3), 395-399. http://doi.org/10.1016/j.apmr.2009.10.021

Dalemans, R. J. P., De Witte, L. P., Beurskens, A. J. H. M., Van den Heuvel, W. J. A., \& Wade, D. T. (2010). An investigation into the social participation of stroke survivors with aphasia. Disability and Rehabilitation, 32(20), 1678-1685. http://doi.org/10.3109/09638281003649938

Dalemans, R. J. P., De Witte, L. P., Wade, D. T., \& Van den Heuvel, W. J. A. (2008). A description of social participation in working-age persons with aphasia: a review of the literature. Aphasiology, 22(10), 1071-1091. http://doi.org/10.1080/02687030701632179

Dalemans, R. J. P., De Witte, L. P., Wade, D. T., \& Van den Heuvel, W. J. A. (2010). Social participation through the eyes of people with aphasia. International Journal of Language \& Communication Disorders, 45(5), 537-50. http://doi.org/10.3109/13682820903223633

Darrigrand, B., Dutheil, S., Michelet, V., Rereau, S., Rousseaux, M., \& Mazaux, J.-M. (2011). Communication impairment and activity limitation in stroke patients with severe aphasia. Disability and Rehabilitation, 33(13-14), 1169-1178. http://doi.org/10.3109/09638288.2010.524271

Dickey, L., Kagan, A., Lindsay, M. P., Fang, J., Rowland, A., \& Black, S. (2010). Incidence and profile of inpatient stroke-induced aphasia in Ontario, Canada. Archives of Physical Medicine and Rehabilitation, 91(2), 196-202. http://doi.org/10.1016/j.apmr.2009.09.020

Engelter, S. T., Gostynski, M., Papa, S., Frei, M., Born, C., Ajdacic-Gross, V., ... Lyrer, P. A. (2006). Epidemiology of aphasia attributable to first ischemic stroke: 
incidence, severity, fluency, etiology, and thrombolysis. Stroke, 37(6), 13791384. http://doi.org/10.1161/01.STR.0000221815.64093.8c

Eslinger, P. J., \& Damasio, A. R. (1981). Age and type of aphasia in patients with stroke. Journal of Neurology, Neurosurgery, \& Psychiatry, 44, 377-381.

Fang, Y., Chen, X., Li, H., Lin, J., Huang, R., \& Zeng, J. (2003). A study on additional early physiotherapy after stroke and factors affecting functional recovery. Clinical Rehabilitation, 17, 608-617. http://doi.org/10.1191/0269215503cr655oa

Fotiadou, D., Northcott, S., Chatzidaki, A., \& Hilari, K. (2014). Aphasia blog talk: how does stroke and aphasia affect the carer and their relationship with the person with aphasia? Aphasiology, 28(11), 1301-1319. http://doi.org/10.1080/02687038.2014.928665

Gauvreau, C. A., Le Dorze, G., Laliberté, M.-P., \& Alary Gauvreau, C. (2016). A pilot study on how speech-language pathologists include social participation in aphasia rehabilitation. Aphasiology, 30(10), 1117-1133.

http://doi.org/10.1080/02687038.2015.1100708

Gialanella, B., Bertolinelli, M., Lissi, M., \& Prometti, P. (2011). Predicting outcome after stroke: the role of aphasia. Disability and Rehabilitation, 33(2), 122-9. http://doi.org/10.3109/09638288.2010.488712

Godefroy, O., Dubois, C., Debachy, B., Leclerc, M., \& Kreisler, A. (2002). Vascular aphasia: main characteristics of patients hospitalized in acute stroke units. Stroke, 33, 702-705.

Graham, J. R., Pereira, S., \& Teasell, R. (2011). Aphasia and return to work in younger stroke survivors. Aphasiology, 25(8), 952-960. http://doi.org/10.1080/02687038.2011.563861

Guest, G., MacQueen, K. M., \& Namey, E. E. (2012). Applied thematic analysis. Thousand Oaks: Sage Publishing.

Hallowell, B. (2017). Aphasia and other acquired neurogenic language disorders. San Diego: Plural Publishing. Pre-publication release.

Hilari, K., Needle, J. J., \& Harrison, K. L. (2012). What are the important factors in 
health-related quality of life for people with aphasia? A systematic review. Archives of Physical Medicine and Rehabilitation, 93(1 SUPPL.), S86-S95.e4. http://doi.org/10.1016/j.apmr.2011.05.028

Hilari, K., \& Northcott, S. (2006). Social support in people with chronic aphasia. Aphasiology, 20(1), 17-36. http://doi.org/10.1080/02687030500279982

Hoffmann, M., \& Chen, R. (2013). The spectrum of aphasia subtypes and etiology in subacute stroke. Journal of Stroke and Cerebrovascular Diseases, 22(8), 13851392. http://doi.org/10.1016/j.jstrokecerebrovasdis.2013.04.017

Isaksen, J. K. (2014). It really makes good sense: the role of outcome evaluation in aphasia therapy in Denmark. International Journal of Language and Communication Disorders, 49(1), 90-99. http://doi.org/10.1111/14606984.12049

Jacobs, B. S., Boden-Albala, B., Lin, I. F., \& Sacco, R. L. (2002). Stroke in the young in the Northern Manhattan stroke study. Stroke, 33(12), 2789-2793. http://doi.org/10.1161/01.STR.0000038988.64376.3A

Kadojić, D., Bijelić, B. R., Radanović, R., Porobić, M., Rimac, J., \& Dikanović, M. (2012). Aphasia in patients with ischemic stroke. Acta Clinica Croatica, 51(2), 221-225. Retrieved from http://www.scopus.com/inward/record.url?eid=2-s2.084871883793\&partnerID=tZOtx3y1

Kagan, A., \& Simmons-Mackie, N. (2007). Beginning with the end: outcome-driven assessment and intervention with life participation in mind. Topics in Language Disorders, 27(4), 309-317.

Kagan, A., Simmons-Mackie, N., Rowland, A., Huijbregts, M., Shumway, E., Mcewen, S., ... Sharp, S. (2008). Counting what counts: a framework for capturing real-life outcomes of aphasia intervention. Aphasiology, 22(3), 258280. http://doi.org/10.1080/02687030701282595

Kang, E. K., Sohn, H. M., Han, M. K., Kim, W., Han, T. R., \& Paik, N. J. (2010). Severity of post-stroke aphasia according to aphasia type and lesion location in Koreans. Journal of Korean Medical Science, 25(1), 123-127. http://doi.org/10.3346/jkms.2010.25.1.123 
Kissela, B. M., Khoury, J. C., Alwell, K., Moomaw, C. J., Woo, D., Adeoye, O., ... Kleindorfer, D. O. (2012). Age at stroke: temporal trends in stroke incidence in a large, biracial population. Neurology, 79(17), 1781-7.

http://doi.org/10.1212/WNL.0b013e318270401d

Kyrozis, A., Potagas, C., Ghika, A., Tsimpouris, P. K., Virvidaki, E. S., \& Vemmos, K. N. (2009). Incidence and predictors of post-stroke aphasia: the Arcadia Stroke Registry. European Journal of Neurology, 16(6), 733-739. http://doi.org/10.1111/j.1468-1331.2009.02580.x

Łapkiewicz, E., \& Grochmal-Bach, B. (2008). Aphasia and changes in the quality of marital relations. Neuropsychologica, 6(3), 237-246.

Laska, A. C., Hellblom, A., Murray, V., Kahan, T., \& Von Arbin, M. (2001). Aphasia in acute stroke and relation to outcome. Journal of Internal Medicine, 249(5), 413422. http://doi.org/10.1046/j.1365-2796.2001.00812.x

Lee, H., Lee, Y., Choi, H., \& Pyun, S. B. (2015). Community integration and quality of life in aphasia after stroke. Yonsei Medical Journal, 56(6), 1694-1702. http://doi.org/10.3349/ymj.2015.56.6.1694

Liang, C. L., Chang, H. W., Lu, K., Lee, T. C., Liliang, P. C., Lu, C. H., \& Chen, H. J. (2001). Early prediction of aphasia outcome in left basal ganglia hemorrhage. Acta Neurologica Scandinavica, 103(3), 148-152. http://doi.org/10.1034/j.16000404.2001.103003148.x

Maredza, M., Bertram, M. Y., Gómez-Olivé, X. F., \& Tollman, S. M. (2016). Burden of stroke attributable to selected lifestyle risk factors in rural South Africa. BMC Public Health, 16(1), 143. http://doi.org/10.1186/s12889-016-2805-7

Maredza, M., Bertram, M. Y., \& Tollman, S. M. (2015). Disease burden of stroke in rural South Africa: an estimate of incidence, mortality and disability adjusted life years. BMC Neurology, 15, 54. http://doi.org/10.1186/s12883-015-0311-7

Matos, M. A., Jesus, L. M. T., \& Cruice, M. (2014). Consequences of stroke and aphasia according to the ICF domains: views of Portuguese people with aphasia, family members and professionals. Aphasiology, 28(7), 771-796. 
Mazaux, J. M., Lagadec, T., De Sèze, M. P., Zongo, D., Asselineau, J., Douce, E., ... Darrigrand, B. (2013). Communication activity in stroke patients with aphasia. Journal of Rehabilitation Medicine, 45(4), 341-346. http://doi.org/10.2340/16501977-1122

Naess, H., Hammersvik, L., \& Skeie, G. O. (2009). Aphasia among young patients with ischemic stroke on long-term follow-up. Journal of Stroke and Cerebrovascular Diseases, 18(4), 247-250. http://doi.org/10.1016/j.jstrokecerebrovasdis.2008.10.005

Northcott, S., Moss, B., Harrison, K., \& Hilari, K. (2016). A systematic review of the impact of stroke on social support and social networks: associated factors and patterns of change. Clinical Rehabilitation, 30(8), 811-831. http://doi.org/10.1177/0269215515602136

Pedersen, P. M., Vinter, K., \& Olsen, T. S. (2004). Aphasia after stroke: type, severity and prognosis: The Copenhagen aphasia study. Cerebrovascular Diseases, 17(1), 35-43. http://doi.org/10.1159/000073896

Plowman, E., Hentz, B., \& Ellis, C. (2012). Post-stroke aphasia prognosis: a review of patient-related and stroke-related factors. Journal of Evaluation in Clinical Practice, 18(3), 689-694. http://doi.org/10.1111/j.1365-2753.2011.01650.x

Pommerehn, J., Delboni, M. C. C., \& Fedosse, E. (2016). International Classification of Functioning, Disability and Health, and aphasia: a study of social participation. CoDAS, 28(2), 132-140. http://doi.org/10.1590/23171782/201620150102

Putaala, J., Metso, A. J., Metso, T. M., Konkola, N., Kraemer, Y., Haapaniemi, E., ... Tatlisumak, T. (2009). Analysis of 1008 consecutive patients aged 15 to 49 with first-ever ischemic stroke: the Helsinki young stroke registry. Stroke, 4O(4), 1195-1203. http://doi.org/10.1161/STROKEAHA.108.529883

Roth, F. P., \& Worthington, C. K. (2005). Treatment resource manual for speechlanguage pathology (3rd ed.). Clifton Park: Thomson Delmar Learning.

Shamseer, L., Moher, D., Clarke, M., Ghersi, D., Liberati, A., Petticrew, M., ... PRISMA-P Group. (2015). Preferred reporting items for systematic review and 
meta-analysis protocols (PRISMA-P) 2015: elaboration and explanation. BMJ (Clinical Research Ed.), 349(3), g7647. http://doi.org/10.1136/bmj.g7647

Thrift, A. G., Cadilhac, D. A., Thayabaranathan, T., Howard, G., Howard, V. J., Rothwell, P. M., \& Donnan, G. A. (2014). Global stroke statistics. International Journal of Stroke, 9(1), 6-18. http://doi.org/10.1111/ijs.12245

Tsouli, S., Kyritsis, A. P., Tsagalis, G., Virvidaki, E., \& Vemmos, K. N. (2009). Significance of aphasia after first-ever acute stroke: impact on early and late outcomes. Neuroepidemiology, 33(2), 96-102. http://doi.org/10.1159/000222091

Wells, G. A., Shea, B., O’Connell, D., Peterson, J., Welch, V., Losos, M., \& Tugwell, P. (2014). The Newcastle-Ottawa Scale (NOS) for assessing the quality of nonrandomised studies in meta-analyses. Retrieved March 30, 2017, from http://www.ohri.ca/programs/clinical_epidemiology/oxford.asp

Willer, B., Ottenbacher, K. J., \& Coad, M. L. (1994). The Community Integration Questionnaire: a comparitive examination. Am J Phys Med Rehabil, 73, 103111.

World Bank Group. (2017). World Bank country and lending groups- country classification. Retrieved May 11, 2017, from https://datahelpdesk.worldbank.org/knowledgebase/articles/906519-world-bankcountry-and-lending-groups

World Health Organization. (2001). International Classification of Functioning, Disability and Health [ICF]. Geneva.

Worrall, L., Sherratt, S., Rogers, P., Howe, T., Hersh, D., Ferguson, A., \& Davidson, B. (2011). What people with aphasia want: their goals according to the ICF. Aphasiology, 25(3), 309-322. http://doi.org/10.1080/02687038.2010.508530 


\section{LIST OF APPENDICES}

Appendix A: $\quad$ PRISMA-P checklist

Appendix B: $\quad$ Newcastle-Ottawa Quality Assessment Scale adapted for crosssectional studies

Appendix C: $\quad$ Proof of submission to Topics in Stroke Rehabilitation 


\section{APPENDIX A: PRISMA-P checklist}

Table 2| PRISMA-P (preferred reporting items for systematic review and meta-analysis protocols) 2015 checklist: recommended items to address in a systematic review protocol

\begin{tabular}{|c|c|c|}
\hline Section and tople & Item No & Checikllst Item \\
\hline \multicolumn{3}{|l|}{ Administrattve Intormation } \\
\hline \multicolumn{3}{|l|}{ Titie: } \\
\hline Identification & $1 \mathrm{a}$ & Idertsfy the report as a probocol of a systamatic ravlaw \\
\hline Update & $1 \mathrm{~b}$ & It the protosol la for an update of a pravlous systamatic reviaw, lisntify as aush \\
\hline Reglatration & 2 & It raglatered, provide the name of the reglstry (sush as PRCGPERO) and rog stration number \\
\hline \multicolumn{3}{|l|}{ Authors: } \\
\hline Contact & sa & $\begin{array}{l}\text { Prowde name, inathutional affllation, e-mal address of all protocol authora; prowde phyalaal malling address of } \\
\text { comasponding author }\end{array}$ \\
\hline Contributiona & $3 b$ & Deacribe contrbutions of pratocol authora and idently the quarantor of the review \\
\hline Amendmenta & 4 & $\begin{array}{l}\text { It the protosol represents an amendment of a previoualy completed or publahed probocol, lidentify as such and llat } \\
\text { changes; othenwae, state plan for documenting Importart protocol amendmants }\end{array}$ \\
\hline \multicolumn{3}{|l|}{ Support } \\
\hline Sources & sa & Ind cate sourcess of financlal or other support for the ravew \\
\hline Sponacr & so & Frowde name for the rawew funder andlor sponaor \\
\hline Rale of aporasor or funder & se & 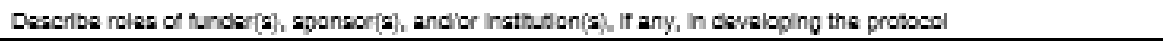 \\
\hline \multicolumn{3}{|l|}{ Introduction } \\
\hline Rationale & 6 & Deacribe the rationale for the revisw in the context of what la alrady lonown \\
\hline Co/ectivas & 7 & 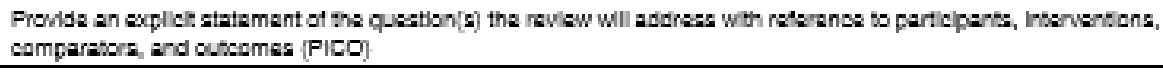 \\
\hline \multicolumn{3}{|l|}{ Methods } \\
\hline Elploilty criterla & 8 & 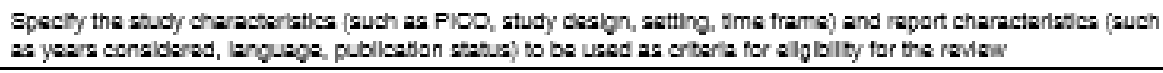 \\
\hline Information sourcea & 9 & $\begin{array}{l}\text { Deacribe al intended information sources (euch as electronic databeacs, contact with stucly authors, trial raplatera } \\
\text { or other grey Iterature sources) with plarned dates of coverape }\end{array}$ \\
\hline Search atratepy & 10 & 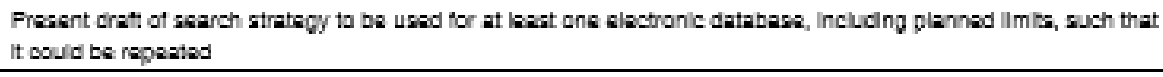 \\
\hline \multicolumn{3}{|l|}{ Study records: } \\
\hline Data management & $11 \mathbf{a}$ & Deacribe the macharlsm(s) that wil be used to maneje records and data throughout the revew \\
\hline Selsction process & $11 b$ & $\begin{array}{l}\text { State the procses that wil be uaed for selesting shudes (sush as two independent reviswers) through each phase } \\
\text { of the raview (that ls, scresening, algibllty and Indusion In mata-aralyala) }\end{array}$ \\
\hline Data collacton prosssa & 110 & 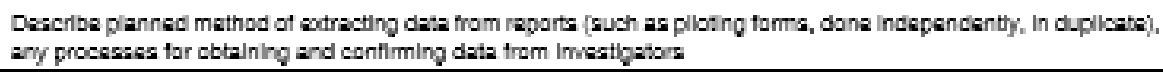 \\
\hline Data liema & 12 & 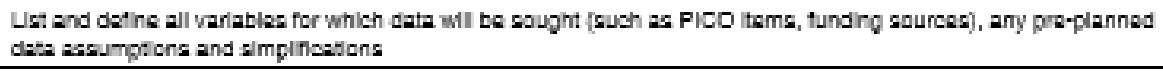 \\
\hline Ouscomes and priartization & 13 & $\begin{array}{l}\text { Ust and detine all outcomes for which clata wil be sought, includino priorttzaton of main and additonal outcomes, } \\
\text { with ratconala }\end{array}$ \\
\hline Risk of blea in Inclvidual atudes & 14 & 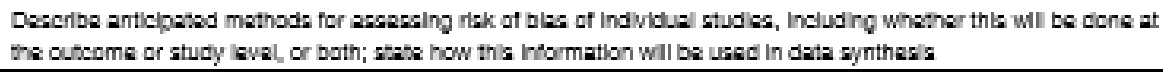 \\
\hline \multirow[t]{4}{*}{ Data syntheala } & $15 a$ & Deacribe crtarla under which study data wil be quantathely syntheslesd \\
\hline & 150 & 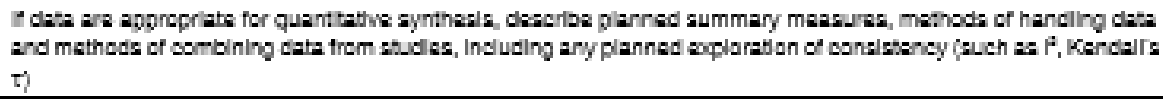 \\
\hline & 150 & Deacribe any proposed additional analyess (sush as senclivity or subproup analyess, mata-represalon) \\
\hline & $15 d$ & It quantatative syntheala la not appropriate, describe the type of aummary plannad \\
\hline Mata-blas'as] & 16 & 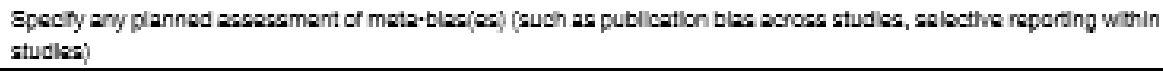 \\
\hline Conflidence In cumuattwe evidence & 17 & Deacribe haw the strangth of the body of ewdence wil be easeased (auch ae GRADE) \\
\hline
\end{tabular}




\section{APPENDIX B: Newcastle-Ottawa Quality Assessment Scale adapted for cross-} sectional studies

\section{Selection:}

1) Representativeness of the sample:

a) Truly representative of the average in the target population. * (all subjects or random sampling)

b) Somewhat representative of the average in the target group. * (non-random sampling)

c) Selected group of users.

d) No description of the derivation of the included subjects.

2) Sample size:
a) Justified and satisfactory. *
b) Not justified.

3) Non-respondents:

a) Comparability between respondents and non-respondents characteristics established and good response rate. *

b) Not satisfactory response rate or comparability between respondents and non-respondents.

c) No description of response rate or responders and non-responders characteristics.

4) Ascertainment of the exposure (risk factor):
a) Validated tool. **
b) Non-validated but available or described tool.*
c) No description.

\section{Comparability:}

1) Comparability of subjects in different outcome groups on the basis of design or analysis. Confounding factors controlled.

a) Study controls for the most important factor (select one). *

b) Study control for any additional factor. *

\section{Outcome:}

1) Assessment of outcome:
a) Independent blind assessment. **
b) Record linkage. **
c) Self report. *
d) No description.

2) Statistical test:
a) Statistical test used to analyze the data clearly described, appropriate and measures of association presented including confidence intervals and probability level ( $p$ value). *

b) Statistical test not appropriate, not described or incomplete 


\section{APPENDIX C: Proof of submission to Topics in Stroke Rehabilitation}

Submission Confirmation for Social participation in working-age adults with aphasia: An updated systematic review

Topics in Stroke Rehabilitation Journal Office <em (i) ditorialmanager com»

11 May (2 days ago) a to me :

CC: alta.kritzinger@up.ac.za, bhavani.pillay@up.ac.za

Dear Ms PIKE,

Your submission entitled "Social participation in working-age adults with aphasia: An updated systematic review" has been received by journal Topics in Stroke Rehabilitation

You will be able to check on the progress of your paper by logging on to Editorial Manager as an author. The URL is http://strokerehab.edmqr.com/.

Your manuscript will be given a reference number once an Editor has been assigned.

Thank you for submitting your work to this journal.

Kind regards,

Topics in Stroke Rehabilitation 